\title{
Parerga to the Stadiasmus Patarensis (15): The Road Network around Kasaba Plain
}

\author{
Fatih ONUR*
}

The road network around Kasaba Plain, as recorded by the Stadiasmus Patarensis (SP), remains for several reasons problematic, even though field surveys have helped to understand the complications to a certain extent. The problem stems from the missing lines of information on the SP: 1) The destination of R58 from Myra is unknown, though there are suggestions such as Mastaura. Figuring out this destination is important for constructing the road network around Dereağzı and Arneai. 2) The SP contains no information on the roads from Arneai to Myra, to Neisa, to Limyra, to Kyaneai, and perhaps to other possible stations (e.g. Dereağzı/Mastaura?, Tragalassos, Trebendai, Phellos?). 3) There is a blank section at the top of Face C of the SP and about 5 roads (5 lines) can fit in this space (apparently corresponding to the missing information mentioned in 2 above). ${ }^{1}$ These issues will be discussed below. What we have in the SP concerning the section mentioned, are only some roads, which are indicated on the map below (Fig. 1).

\section{The Destination of R58}

The editor reports for R 58 "There were ca. 4 letters on the left edge of the block. A vertical stroke belonging to the next letter is barely identifiable. After this, nothing can be read in the space of ca. 8 letters. On the right edge of the block, there are remains belonging to the bottom sections of two letters: $\angle$ I. They may be taken as $\sum \mathrm{I}, \Sigma \mathrm{T}$ or $\Delta \mathrm{I}^{\prime 2}$ and gives the transcription below:

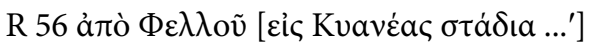

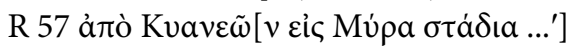
(The road) from Phellos (leading) to Kyaneai ... stadia

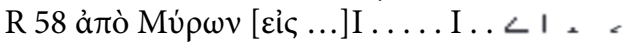
(The road) from Kyaneai (leading) to Myra ... stadia

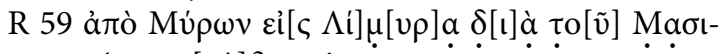

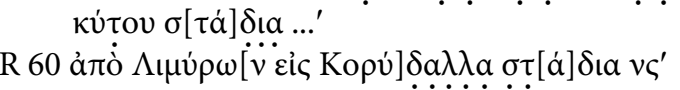
(The road) from Myra (leading) to ...
(The road) from Myra (leading) to Limyra through (the Mount) Masikytos ... stadia
(The road) from Limyra (leading) to Korydalla 56 stadia

\footnotetext{
* Assoc. Prof. Dr. Fatih Onur, Akdeniz Üniversitesi, Edebiyat Fakültesi, Eskiçağ Dilleri ve Kültürleri Bölümü, Kampüs 07058 Antalya (fatihonur@akdeniz.edu.tr).

This contribution was accomplished after the results of the on-going "Stadiasmus Patarensis" field surveys directed by the late Prof. Sencer Şahin until 2014 and hereafter by Prof. N. Eda Akyürek Şahin with the permission from the Turkish Ministry of Culture and Tourism. The field surveys, some results of which are included in this contribution, were supported by “The Scientific and Technological Research Council of Turkey” (TÜBİTAK, project no. 108K437) in 2009-2011, by the Akdeniz University Scientific Research Projects Coordination Unit (project no.: SBA-2015-937, conducted by Prof. N. Eda Akyürek Şahin) and by the Science Academy in Turkey through the programme of "Young Scientist Awards (BAGEP)". I am indebted to all the mentioned institutions for their support. I thank Diether Schürr for his remarks, and also Christof Schuler and Hüseyin Sami Öztürk, who indicated some important matters concerning the settlement at Muskar (see here fn. 26).

${ }^{1}$ Şahin - Adak 2007, 208-211; Şahin 2014, 274-281.

2 Translated from Şahin 2014, 370-371: "Bloğun sol kenarında yak. 4 harf bulunmaktaydı. Bunu takip eden harften ise taş üzerinde dikey bir çizgi zorlukla tanınabilmektedir. Bundan sonraki yak. 8 harflik boşlukta hiçbir şey okunamamaktadır. Bloğun sağ kenarında ise iki harfin alt kısımlarına ait kalıntılar gözükmektedir: $<$ ।. Bunlar da $\sum$ I ya da $\Sigma$ T veya $\Delta$ I olarak anlaşılabilirler.”
} 


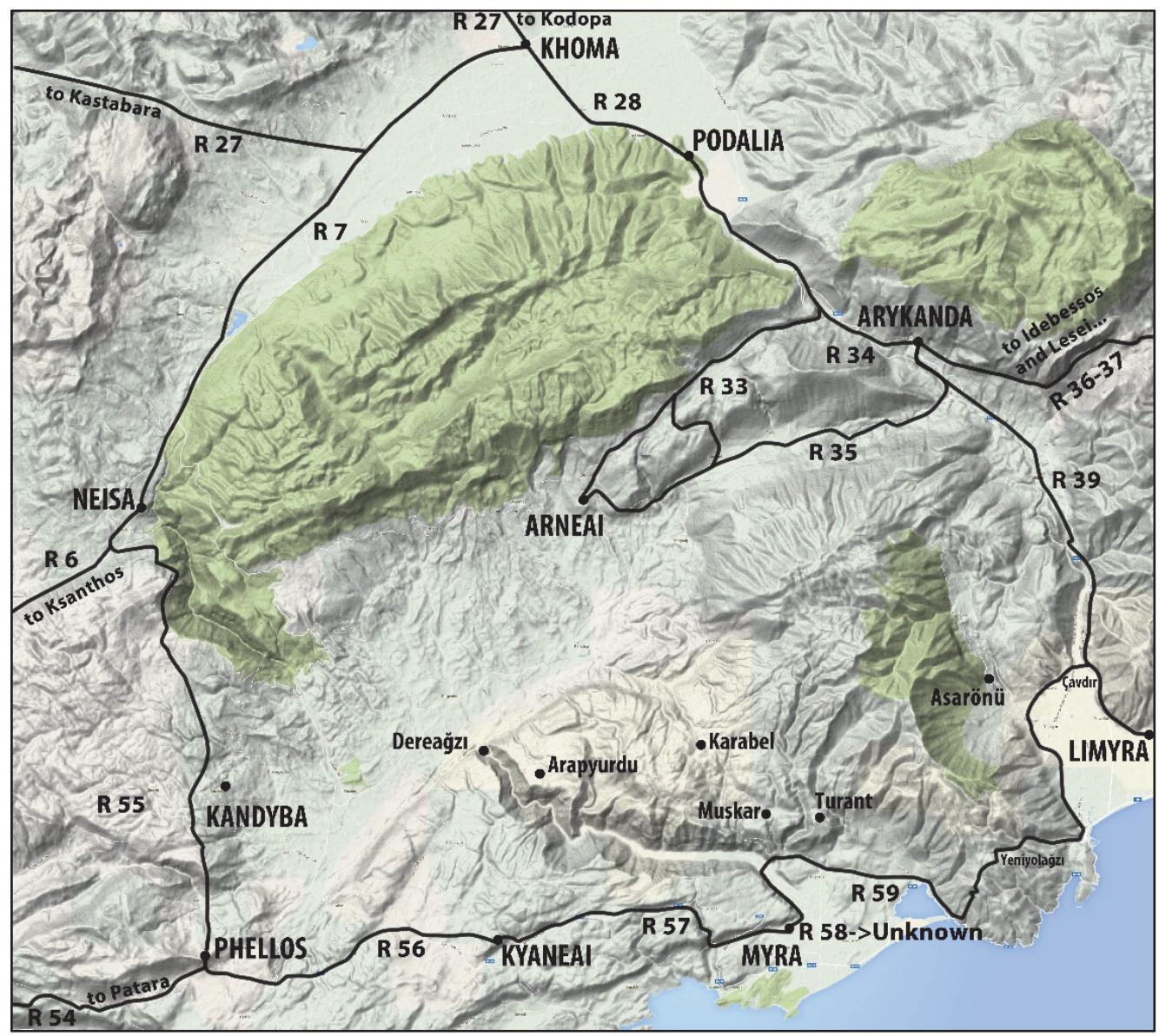

Fig. 1) Theoretical courses of the roads recorded in the SP, concerning the Kasaba region

There is no doubt that the restoration of R 59 is secure as the road from Myra led to Limyra through Mount Masikytos and both Arneai and Dereağzı (Mastaura?) have been proposed as the destination of R 58. If this can be restored correctly, it will help in the solution of other problems concerning this issue.

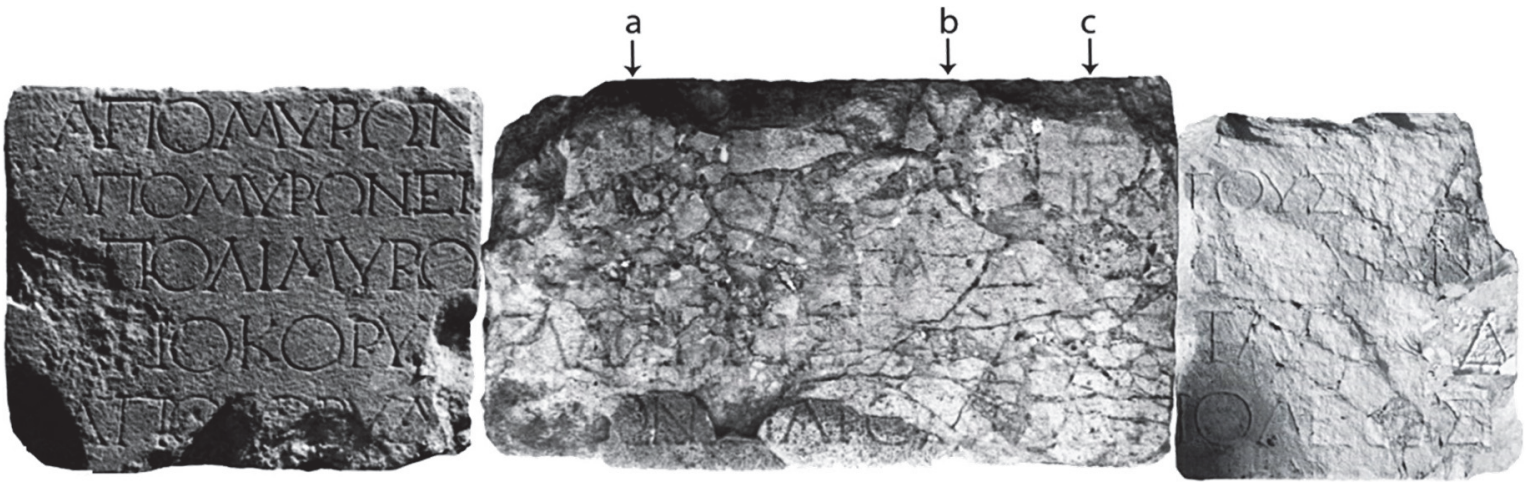

Fig. 2) R 58-62 (Şahin 2014, 370)

The lacuna after $\mathrm{A} \Pi \mathrm{M} \Upsilon \mathrm{P} \Omega \mathrm{N}$ in the first line (R58) appears to be filled with 12 letters at least to the end of the middle block, plus at most ca. 8 additional letters to the end of the right block (20 in total). The first three letters should be restored as EI $\Sigma$, at least 6 letters are for $\Sigma$ TA $\Delta$ IA and at least

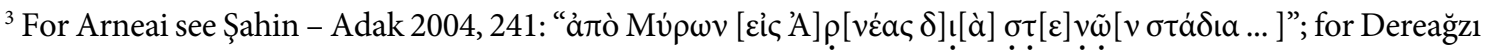

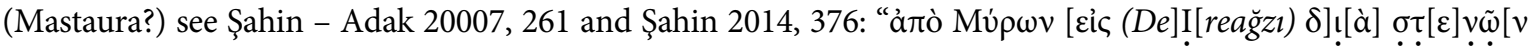

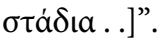


one letter for the distance, so what space remained for the name of the settlement comprises 10 letters at most, which can be reduced to 8 since there is occasionally a vacant before $\Sigma$ TA $\Delta \mathrm{IA}$ and the distance. So the name of the settlement in accusative form after EI $\Sigma$ is ca. 8-10 letters. Further, the letter after EI $\Sigma$ appears to have a vertical stroke (see Fig. 2, a), which does not have horizontal lines at the bottom and another vertical stroke is visible after ca. 5 letters (see Fig. 2, b), and then comes $\sum$ I, $\Sigma$ T or $\Delta \mathrm{I}$ (see Fig. $2, \mathrm{c}$ ) after a lacuna of two letters. So the name of the settlement should fit the lacuna and these remaining traces. The possible destinations might be Arneai, Andriake, Dereağzı (Mastaura?) or Tragalassos. I should add Trebendai, and one might even supply another settlement, known or unknown, in this lacuna (see fn. 26 below). All these names, except for Arneai, which is too short, and Tragalassos, which appears to be somewhat long (see Fig. 4), fit this space. Andriake and Dereağzı (Mastaura?) have been discussed by Şahin.. He thinks that Andriake is not suitable because it is a port and no ports are given in the SP except for Kalabatia. ${ }^{5} \mathrm{I}$ also find Andriake impossible, following the principle that the settlements mentioned on the SP were autonomous in the reign of Claudius, as has been discussed in another paper ${ }^{6}$, while Andriake was the dependent port of Myra. But Şahin found Dereağzı (Mastaura?) plausible and lastly proposed the following restoration: "åmò

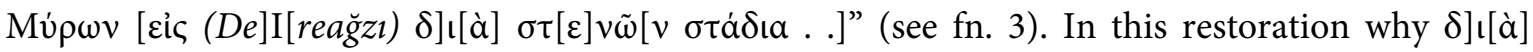
$\sigma \tau[\varepsilon] \nu \tilde{\omega}[v$ is employed is not clear. If this is understood as a natural formation in meaning "straits", it would normally have had an article (i.e. $\tau \tilde{\omega} v)$. Even if we accept that $\tau \tilde{\omega} v$ was omitted due to a shortage of space, the expression lacks an explanation. In the case of the two roads from Oinoanda to Balboura, which were listed sequentially in two sentences connected with $\delta \varepsilon$, (R 22-23, side B, 1.30-

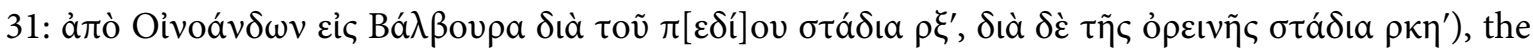
explanatory detail can be understood, since one road run through the plain, the other was via the

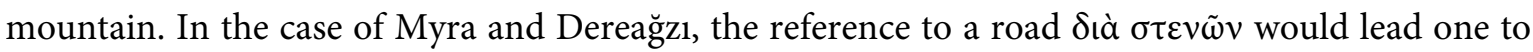
expect a sequential road following another route, but this is not indicated on the SP. If $\Sigma \tau \varepsilon v a ́ / \eta ́$ or aí/ó is taken as a place name, which was not the case presented by Şahin, then we would have to assume the existence of an otherwise unattested autonomous settlement called $\Sigma \tau \varepsilon v$ - between Myra and Dereağzi. Further, the restoration seems to be at least five letters longer than the lacuna and does not really fit the remaining traces (see Fig. 3).

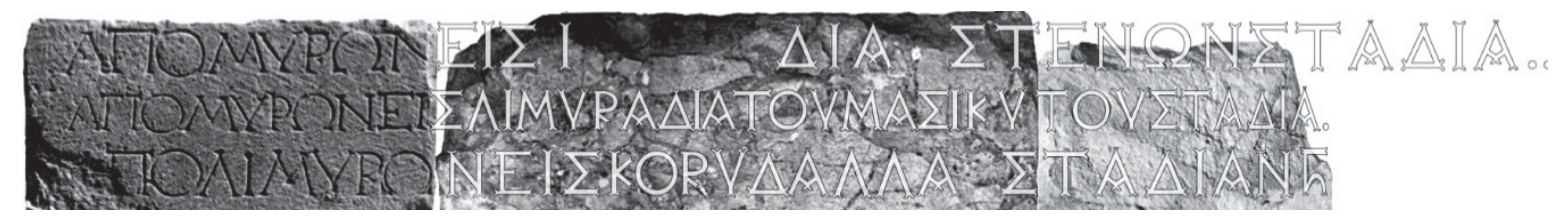

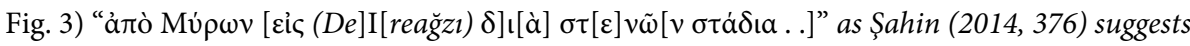

Dereağzı (Mastaura?) could perhaps be an option if it was autonomous in the time of Claudius. But the evidence does not support this, since Mastaura, which is known as a Lycian bishopric only through Byzantine sources from the $8^{\text {th }}$ c. onwards, appears only to have been a dependency of Myra in its earlier history, ${ }^{7}$ as Myra's water canal starts from north of Dereağzı. Further, if we take Dereağzı (Mastaura?) as a station of the SP, understanding it to be an autonomous settlement, this creates more problems in terms of the road listing for the blank section (see below). Tragalassos, another

\footnotetext{
${ }^{4}$ Şahin - Adak 2007, 110-111, 209-211 and 259-261; Şahin 2014, 114-115, 275-280 and 371-374.

${ }^{5}$ Şahin 2014, 371.

${ }^{6}$ Onur 2015.

${ }^{7}$ Foss 1994, 33; for more on Mastaura see Hellenkemper - Hild 2004, II, 716-717.
} 
option, was an autonomous settlement in the Hellenistic period according to an inscription from Arykanda, which mentions a symmachy between these two cities. ${ }^{8}$ But no evidence on this settlement is known until the time of St. Nicholas of Sion, who was born in and lived around Tragalassos in the $6^{\text {th }}$ c. A.D. The monastery of Holy Sion in Tragalassos was localized at Asarcik near Karabel by Harrison ${ }^{9}$, who is followed by others ${ }^{10}$, while Chronz $^{11}$ and then Hellenkemper \& Hild ${ }^{12}$ proposed the monolithic church in Alacahisar, ca. 3,5 km southwest of Karabel, for this monastery. Tragalassos is localized at Karabel by Şahin ${ }^{13}$, at Muskar by Hellenkemper and Hild ${ }^{14}$, at Asarcık near Karabel by İşler ${ }^{15}$ and finally at the ruins around Arapyurdu by Alkan. ${ }^{16}$ Çevik supports the localization in Muskar. ${ }^{17}$ According to Alkan, Tragalassos should have been in a strategically important location, ${ }^{18}$ perhaps controlling some important roads or passages. The territory around Arapyurdu appears to meet these conditions, as it could watch both the narrows of Myros valley and the Kasaba Plain up to the Çamlıbel pass where the road led from Arykanda to Arneai (R 35). In this case, it was not exactly on the mountainous road from Myra to Arneai. It is also unknown if Tragalassos was autonomous in the Roman period and, even so, if its territory extended so far to the east.

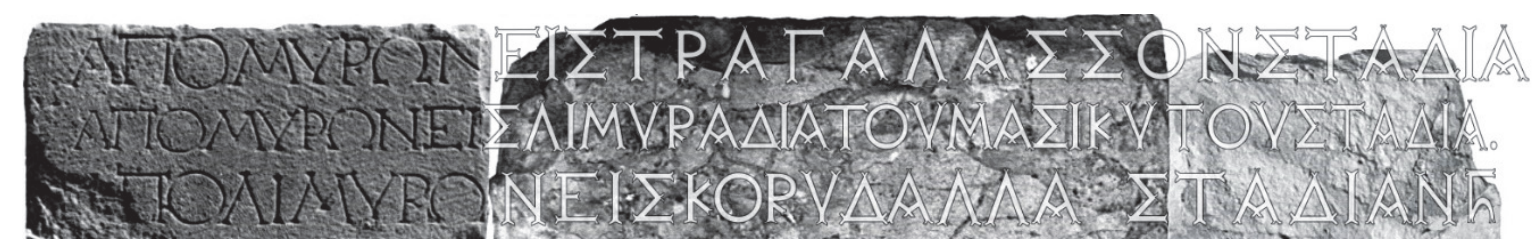

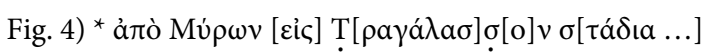

Trebendai might seem to fit the conditions better. The restoration fits the physical remains on the stone (see Fig. 5) and the place had suitable political status. The probable inclusion of Trebendai in the SP has already been pointed out by Alkan, who localises it at Muskar/Belören (Fig. 28 - Fig. 29). ${ }^{19}$ This localisation was previously proposed by Zimmermann. ${ }^{20}$ The history of the Trebendai is not known very well, but we have enough evidence to show that it was an independent settlement. Some Hellenistic confederative Lycian coins with the legend of TP are ascribed to Trebendai. ${ }^{21}$ The ruins in Turant were proposed to have been within its territory, ${ }^{22}$ since according to an inscription on a sarcophagus in Turant the tomb violation fine is to be paid to the community of Eleuthera, which is

\footnotetext{
${ }^{8}$ IArykanda 1 p. 5; for a detailed account on the inscription see Schuler 2014.

${ }^{9}$ Harrison 1963, 131-135 and 150.

${ }^{10}$ Foss 1991, 309; Blum 1997, 12 and 93.

${ }^{11}$ Chronz 1985, 75.

${ }^{12}$ Hellenkemper - Hild 2004, II, 852-856.

${ }^{13}$ IArykanda 1 p. 3; Şahin 2014, 278-279, 282 fig. a.

${ }^{14}$ Hellenkemper - Hild 2004, II, 890-892.

15 İşler 2010, 238.

${ }^{16}$ Alkan 2011a, 101-104; cf. Schuler 2014, 295-296.

${ }^{17}$ Çevik 2015, 352.

${ }^{18}$ Alkan 2011a, 102.

${ }^{19}$ Alkan 2011a, 111-113; Alkan 2011b, 36-37.

${ }^{20}$ Zimmermann 1992, 115; Zimmermann 2002, 776.

${ }^{21}$ Troxell 1982, 39 nos. 55-57; cf. Jameson 1980, 842.

${ }^{22}$ Alkan 2011a,113; Alkan 2011b, 36.
} 


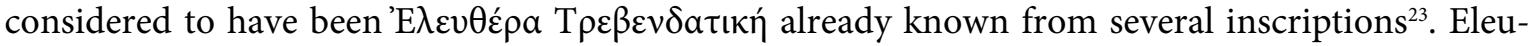
thera is also mentioned in the Hellenistic inscription found in the fortress at Asarbelen Tepesi in

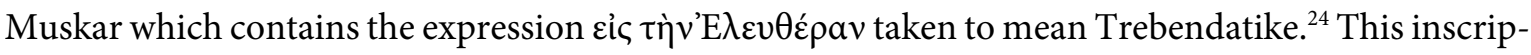
tion contains a decree and the editor thinks a very illegible part in line 8 can be restored as [... है $\delta o] \xi[\varepsilon$ $\tau \tilde{\omega} \iota \mathrm{T} \rho \varepsilon \beta \varepsilon v \delta \alpha] \tau[\tilde{\omega}] \nu \delta \dot{\eta} \mu \omega[\iota]$, suggesting that the name of the settlement is Trebendai. ${ }^{25}$ But a revision of this inscription by Christof Schuler and Hüseyin Sami Öztürk indicites that the name of settlement at Muskar was not Trebendai. ${ }^{26}$ Trebendai also became a member of a sympolity headed by Myra during the Roman period according to a funerary inscription ${ }^{27}$ from Teimiussa / Tristomon (Üçăğ Liman1). This makes it certain that Trebendai was near to Myra. ${ }^{28}$ Ptolemaios mentions Trebendai as a polis amongst the cities around Masikytos ${ }^{29}$. Borchhardt suggested Gürses for Trebendai ${ }^{30}$, but if this were the case, Trebendai would have been expected to appear after Kyaneai and before Myra in the SP. Trebendai is also recorded in the inscription of Jason from Kyaneai amongst other poleis of Lycia, as it honoured Jason in 137 A.D. ${ }^{31}$ Since Trebendai cannot be localized at Muskar, I can perhaps propose to localize it at Turant, where Eleuthera is recorded on the sarcophagus made by a Theophrastos from Kyaneai. But there is no evidence for this, although the name "Turant" is not Turkish and it seems to evoke an altered form of the name Trebendai. So the evidence indicates that this city should have been listed on the way to the north-northeast, consequently it seems the best option to date for the destination of R 58 and the text should, if this is the case, be restored as ámò

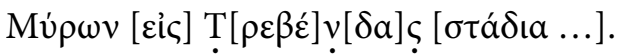

${ }^{23}$ Heberdey - Kalinka 1897, 17 no. 53 (Simena); Bean 1962, 2.4 (Myra); Wörrle 1999b, 272, no. 10 (Limyra); cf. Frei 1990, 1787-1791 (Eleuthera).

${ }^{24}$ Alkan 2011b, 111, line 11.

${ }^{25}$ Alkan 2011b, 111-112.

${ }^{26}$ Schuler 2014, 295, fn. 63; I much appreciate the scholarly collaboration extended by Christof Schuler and Hüseyin Sami Öztürk, who shared this important information with me just prior to the publication of this paper. This has led me to think more of my second option, Turant as Trebendai. According to their revision, which will be published shortly, a section in the inscription indicates a different name. This place might have also been included in the SP, if it remained an independent settlement into the reign of Claudius. It was also stated that the name of the settlement at Muskar was not Tragalassos in Öztürk 2011, 209 fn. 2, referring to this same inscription.

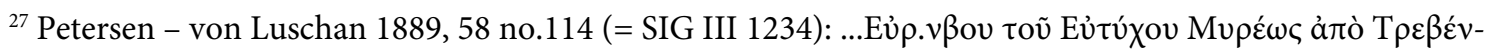
$\delta \omega v \ldots$

${ }^{28}$ Zimmermann 1992, 115; Çevik $(2015,350)$ mentions an unpublished funerary inscription from Gürses, recording a sympolity between Myra and Trebendai.

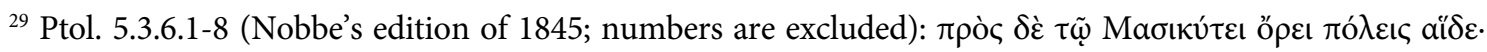

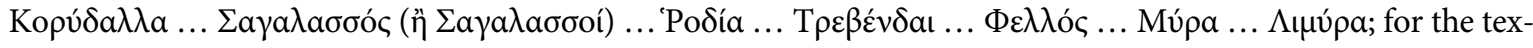
tual comments on Arabendai/Trebendai or Arykanda see Troxell 1982, 57; Ruge 1937, 2267; Magie 1950, II, 1391 note 59; Robert 1955, 206 note 6.

${ }^{30}$ Borchhardt 1975, 82.

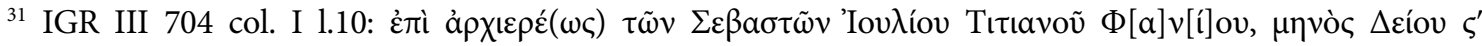

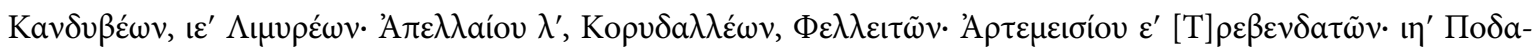
$\lambda_{\iota} \omega \tau \tilde{\omega}[v]$; see also Zimmermann 1992, 252. 


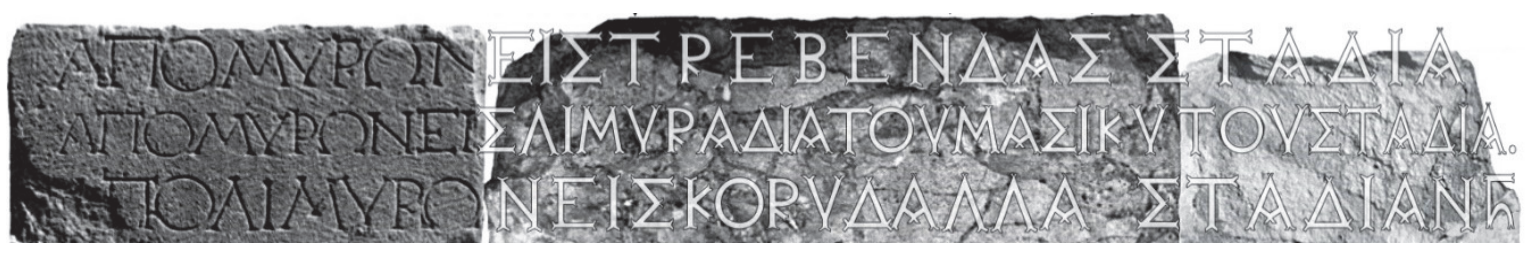

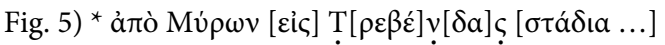

\section{The absence of some roads in the Kasaba Plain and the blank section}

It is curious why some important connections on the Kasaba Plain are missing from the entire monument. Connections from Arneai to major settlements such as Myra, Neisa, Kyaneai and Limyra, and perhaps to Trebendai, Tragalassos, Kandyba and even to Phellos are absent. This situation may be explained by the supposition that the roads in this region had not been completed by time of the erection of the monument, and these roads were probably recorded later with painted letters. ${ }^{32}$ There is also a blank section where these roads might well have been recorded, corresponding with this absence, since it fits with the geographic flow of the text. Face B ends with the road from Arykanda to Limyra (R 39), then the list continues on Face $\mathrm{C}$ with the road from Idebessos to Akalissos ( $\mathrm{R} 40$ ) following the blank section, on which there is not a single trace of carving. Several restorations of this blank section were suggested by Şahin, the first one, made before field surveys were undertaken, as follows:
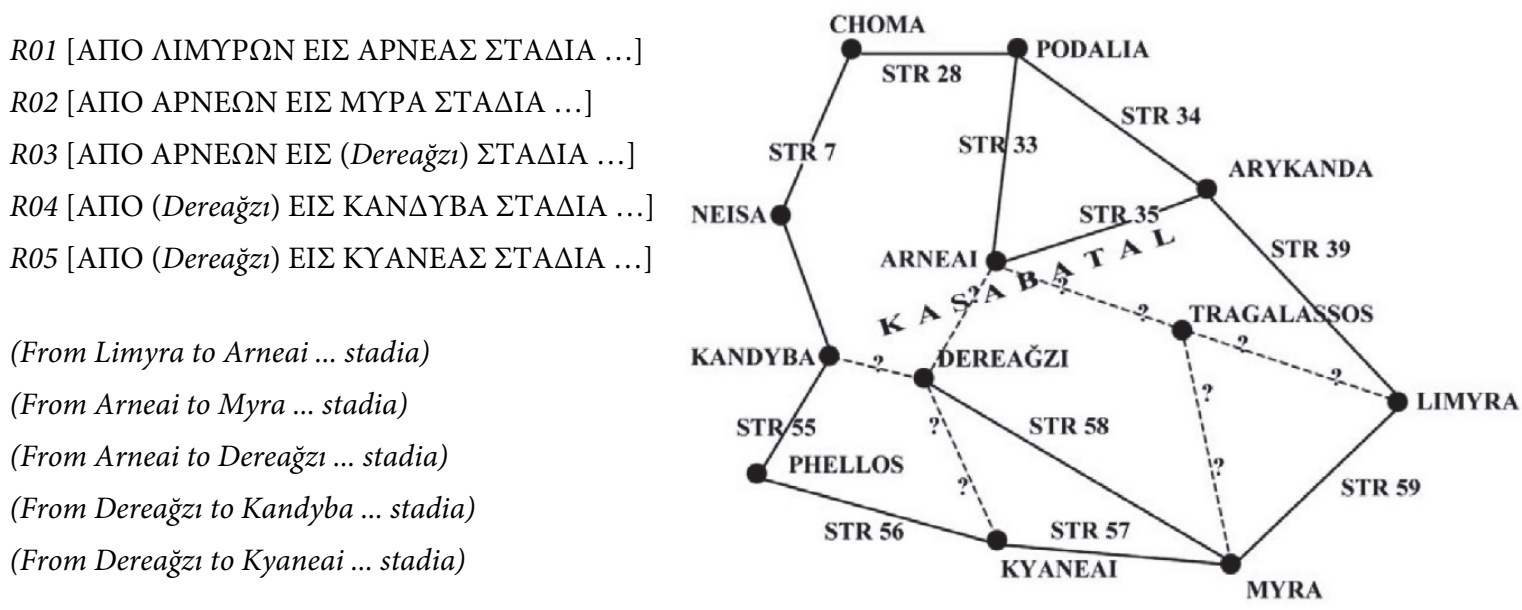

Fig. 6) First proposal in Şahin - Adak 2007, 211. Tragalassos is added by Şahin only in the drawing.

In this proposal, a connection is suggested between Limyra and Arneai, as it is suitable to start the origin with Limyra since face B ends with the road from Arykanda to Limyra and this fits the geographical situation. This hypothetical reconstruction of the text proposes a direct connection between Myra and Arneai, and implies that Myra and Arneai were neighbours having no autonomous settlements between them. But in this schematic plan Tragalassos in the mountainous area on Alacadağ needs to be taken into consideration as a settlement between Limyra and Arneai. Additionally, the proposal also presupposes an indirect connection from Myra to Arneai via Dereağzı through the Myros Valley (R $58+$ R 03), since the editor accepts Dereağzı (Mastaura?) as the destination of R 58 . This should consequently be a station of the SP, from where two more roads to Kandyba and Kyaneai are proposed.

Apparently, a surface scan on this blank section of the stones through instruments such as Raman

${ }^{32}$ Şahin - Adak 2007, 208; Şahin 2014, 275 and 279. 
Spectroscopes, UV light and raking photography may be required in order to understand if there are any remains of colour and, if there is, what the actual roads were recorded in this blank section were.

\section{An outline of the remains on the field}

The roads around this region have been partly investigated and published following several researches as is shown below. We also completed a field survey in 2010 and 2011, and were able in part to solve the problems mentioned above. I will present a brief description of the roads in the relevant part of Lycia.

\section{Southeast - Northwest Axis (Myra - Kandyba/Neisa)}

A road connection between Myra and Kandyba-Neisa running through the Kasaba Plain was no doubt inevitable in view of the socio-cultural and commercial relations and also the geographical situation of these cities. So this cannot actually have been omitted in the planning of SP. There is also remarkable evidence on the field.

Myra - Dereağzi: The roads along both banks of the Myros River are already known and partly investigated. ${ }^{33}$ The road leading to the entrance of the straits on the eastern side of Dereağzı (where the Tokluca River flows) and along the eastern bank of the river to Myra (Fig. 11, Fig. 12, Fig. 13) could mostly be followed from Gavuryolu, which starts near Gödeme and which leads over the mountain to Muskar and Arneai. The details of this road were published as R 58 by Şahin ${ }^{34}$, who accepts Dereağzı (Mastaura?) as the destination of $\mathrm{R} 58$. The road leading along the western bank of the river was also reported (see fn. 33). This road was necessary at least for the maintenance of the water canal running from the Kibris Gorge to Myra, passing through the rock-cut tombs in the eastern necropolis of Myra. ${ }^{35}$

Dereağzı - Kandyba/Neisa: The remnants of a road to the north of Dereağzı probably belonged to the road leading to Kandyba/Neisa and Arneai. ${ }^{36} \mathrm{~A}$ road to Neisa seems possible through Gömüce and Kuruova, leading from the route indicated by French. ${ }^{37}$ The road to the south of Kandyba (Fig. 14 ), which we recorded in our field survey of 2009, might also have been a part of this connection, ${ }^{38}$ if the road led from Myra to Neisa through Kandyba or to Kandyba directly (see R 04b on the map in Fig. 8). Most of this area should have been within the territory of Myra, since its water canal takes its source from the Kibris/Kasaba River to the south of Neisa. The course of this water canal seems to have been used till recent times to drive the mills, which are now out of use. The first mill to the north is the Cüce ("dwarf") Mill at the end of the Kibris Valley on the eastern bank of the river. Remains of a bridge from the Byzantine/Seljuk? period are visible in the town of Kemer ("arch") 400 $\mathrm{m}$ to the south. The Ferhat Ağa Mill is another $400 \mathrm{~m}$ to the south on the western bank. This shows that the aqueduct passed the river somewhere in between these mills, probably near or via the bridge mentioned. $400 \mathrm{~m}$ south of the Ferhat Ağa Mill is the Yusuf Ağa Mill, followed by the Çelikel Mill

\footnotetext{
${ }^{33}$ Morganstern 1968, 224; French 1993, 87-90 and for the references to earlier testimony see fn. 2; Hellenkemper - Hild 2004, I, 267 and III, figs. 262-264.

${ }^{34}$ Şahin 2014, 375-376, for the photos see 435 figs. a-b, 436 figs. d-f, and 437-438.

${ }^{35}$ See Borchhardt 1975, 47 and pl. 10C.

${ }^{36}$ French 1993, 87 and pl. 15.1.

${ }^{37}$ French 1993, 87 and see the map pl. 16.

${ }^{38}$ Şahin 2014, 279.
} 
1400 m south, Hayri Bey Mill 2500 m south, Totaman Mill 3100 m and lastly the Koştur Mill 250 m to the south. ${ }^{39}$ These mills indicate the course of the ancient canal which continues from the right bank of Kıbrıs/Kasaba River until it enters the narrows from the western side of Dereağzı.

\section{Southwest - Northeast Axis (Kyaneai - Arneai)}

There was no doubt a connection between Kyaneai and Arneai, since road remains have been found in both directions from Dereağz1. However, even if this was recorded in SP, it would probably have been given "through Myra", since such a road would pass through the northern territory of Myra. But in SP, there are not many cross connections, for example no roads are given between Xanthos and Phellos or between Patara and Neisa. Further, there is no settlement which is mentioned both as an origin/destination and as an intermediate town (used with $\delta$ iá), except for Rhodiapolis, which was the destination of a road only from Lesei- and which is mentioned on the road from Korydalla to Akalissos, which passed through its territory.

Kyaneai - Dereağzi: The field surveys of 2010 concluded that there was a road, with a width of 2,5-3 m, from Kyaneai to Dereağzı, passing through Köte, Küçükçerler, Ağalar, the Çerler pass (west of Gökçeyazı), Korba and Gürlü (Fig. 15) and this road probably connected to the bridge over the Kasaba River at the western foot of Dereağzı Hill, of which only the hollow footings in the rock for the wooden structure remain (Fig. 16-Fig. 18; see also Şahin 2014, 277).

Dereağzı - Arneai: The road mentioned above starting north of Dereağzı (see above fns. 36-37) should have split to two directions. While one leads in the direction of Neisa, the other should lead to Arneai through Dirgenler, Doğantaş, Karadağ, the old caravan route according to local informants..$^{40}$

\section{The roads on Alacadağ and Bonda}

Myra - Arneai: Field research showed that there is a continuous road starting from Gavuryolu (at the north of Gödeme near Köşkerler) to Arneai, passing through Muskar, Karabel, Çağman and Dağbağ. A detailed account of this road was published by Takmer and Alkan. ${ }^{41}$ In the SP this road from Myra was probably not marked to Arneai directly, but most likely took the form of two roads, first from Myra to Trebendai/Tragalassos (R 58) and second from Trebendai/Tragalassos to Arneai (see R 02 on the map in Fig. 8).

Limyra - Arneai?: There are paths from the higher levels of the Alacadağ Mountain, which can be reached from Limyra through the towns of Asarönü, which was a peripolion of Limyra ${ }^{42}$, and Alacadağ. It might have descended to reach Çağman (see R 01a on the map in Fig. 8), where another road led to Arneai (see above and R 02 on the map in Fig. 8). ${ }^{43}$ But such a road would apparently be quite steep and hard. It is known that a road from Asarönü led to Adala. ${ }^{44}$ After Adala, it probably led into the territory of Arykanda near Gökbük through the Valley of the Şırlan Deresi, where boundary (?) inscriptions remained on the bed rock by the passage (Fig. 19), like those on the southern side

\footnotetext{
${ }^{39}$ Şahin 2014, 373, for the mills see fn. 712.

${ }^{40}$ Şahin 2014, 277.

${ }^{41}$ Takmer - Alkan 2013, 110-113.

42 Wörrle 1999a, 357-359.

${ }^{43}$ Şahin 2014, 278.

${ }^{44}$ Wörrle 1999a, 357.
} 
of the pass between Arneai and Arykanda. ${ }^{45}$

Most of the course of the road between Limyra - Myra can be followed. ${ }^{46}$ This road might have split into two or more tracks at Yeniyolağzı at the southern foot of Dinek Tepe, at least one of them leading to Myra and another one probably to Muskar perhaps through Turant.

Limyra - Yeniyolağzı/Damyanı: A road led west from Limyra passing Arykandos near Çavdır in the north of Turunçova, where two milestones were found. ${ }^{47}$ The traces of the road, which was probably connected with the one mentioned formerly, continue after Finike and can be followed up to Yalakbaşı through the valley of Yalakdibi, at beginning of which is a Hellenistic tower, obviously constructed to watch over the ancient road (Fig. 20). The road continues, passing by Yalakbaşı, where there is a small settlement ${ }^{48}$, along the Kasap Deresi. Some fifty meters south of the end of the Kasap Deresi and five meters south of the modern stabilized road is a milestone ${ }^{49}$ dedicated by the city of Limyra to the Augusti Diocletianus and Maximianus, and to the Caesares Constantius and Galerius, so dated A.D. 293-305 (Fig. 21). The distance given on the milestone is reported by Şahin as 6 miles $(=$ ca. $9 \mathrm{~km})$. This place is in the southern vicinity and close to Dinek Hill, where there is also a small settlement belonging to Limyra, as the inscriptions from this place record..$^{50}$ It is stated that the only way from Limyra to Myra should pass through Çavdır, where the milestones were found (see above fn. 47), but the distance on the milestone from Yeniyolağzı, which should be from Limyra, does not seem to correspond to the distance via Çavdır, since 6 miles $(\mathrm{ca} .9 \mathrm{~km})$ is insufficient to cover the required bend in the road to the north around the plain near Turunçova. Only direct connections from Yeniyolağzı to Finike and from Finike to Limyra could be measured at 9-10 km, not even allowing for any zigzags, passing directly through the Finike Plain to Limyra. Though geomorphological research on the Finike Plain has shown that Finike Plain started to lose its water ca. 3500-4000 years ago ${ }^{51}$, this area has always been boggy and even ploughing the fields is not possible for the most of the year. The main access to Finike was always via Çavdır, as the locals narrate today. Since the milestone was found erected and fixed into the ground, but upside down, at least indicating its reuse, one should ask if it had been carried from somewhere else. But its transportation from somewhere else seems quite improbable as a distance the 9-10 km of this road from Limyra would lead to find a location somewhere between Finike and Asarönü on the plain, while the locals reported that they themselves erected the milestone, which was lying by its find spot on the ancient road. A reinspection of the milestone showed that the visible number of miles recorded was not $\varsigma$ (6), but $\varepsilon$ (5), which would therefore most probably have been followed by an I (10), since there seems to be no room on the stone before it (see Fig. 22). If so, it records 15 miles, which is around 21-22 km, conforming with the actual distance from Yeniyolağzı to Limyra via Çavdır.

\footnotetext{
${ }^{45}$ Uzunoğlu - Taşdelen 2013, 129.

${ }^{46}$ See details in Marksteiner - Wörrle 2002, 550-555; Takmer 2004, 110-113; Şahin - Adak 2007, 263-265; Şahin 2014, 379-387.

${ }^{47}$ French 1988, 75 no. 196; Takmer 2004, 107-108 no. 1; French 2014, 69 no. 32(A).

${ }^{48}$ See the description in Marksteiner 2004, 276 and Marksteiner et al. 2007; also in Şahin 2014, 385.

${ }^{49}$ The milestone we discovered in our field surveys is not as yet published, but mentioned by Şahin 2014, 385 .

${ }^{50}$ Wörrle 2012, 452-453 nos. 80-81; for the description of the remains in the settlements see also Marksteiner 2004, 280-281.

${ }^{51}$ Öner 1996, 134 and see the maps at the end.
} 
Yeniyolağzı /Damyanı - Myra: After Yeniyolağzı near Damyanı there are roads in the directions of Dinek Hill, Belen/Belos and Myra. The road to Myra leads in the direction of Kaklık through Damyanı, where there is a small ancient settlement today called "Ortasarı", belonging to Limyra in antiquity. ${ }^{52}$ Another milestone was discovered in our field surveys just before Kaklık ${ }^{53}$, where there is a Hellenistic farmstead and an Early Hellenistic rock-cut tomb belonging to a certain Kendas and his family (Fig. 23). ${ }^{54}$ This milestone rolled down to the road and its place of erection is known from its location hole by the road (Fig. 24). It is again from the first tetrarchy and unfortunately the distance number, which would be from Myra, is unknown, since the bottom section is missing. But most probably it was between 10 and 15 (ca. 14,5 to $21 \mathrm{~km}$ ), basing on the probable distance between these two points. The famous Claudian Monument occurs after $200 \mathrm{~m}$ at an altitude of $753 \mathrm{~m}$ (Fig. 25-Fig. 26). ${ }^{55}$ From this point onwards the road, the width of which hereafter reaches 3,5-4 m, descends with zigzags down to the south-eastern corner of the lagoon of Beymelek (Fig. 27). ${ }^{56}$ Then it probably continued either in the direction of Yukarı Beymelek, reaching a point near Gödeme, joining R 58 (that is from Myra to Trebendai), and passing over the Myros river by a bridge used for both before it reached Myra, or, as a slim possibility, led straight-forwardly in the direction of Myra passing a bridge in the south, which might have been demolished by the great floods that have filled the area with alluvium. ${ }^{57}$

Yeniyolağzı/Damyanı - to other settlements: Apart from Myra, at least two roads seem to have taken different courses from Damyanı. One is to the Belen/Belos ${ }^{58}$ immediately to the east of Damyanı. No connection is known beyond this settlement, though there is a path to the northwest, which disappears shortly after, but it is possible that there was a connection at least to the ruins in Karacaören and Günağ 1 Church, or to the Alakilise Valley, it is possible to reach Muskar/Belören from both places through Turant (for the former) and Zeytin (for the latter). The road that leads through Dinek Tepe might have taken a route at a higher altitude passing through Tepsili and Yatıkardıç, which is also a part of Lycian Way, finally reaching the northeast ends of Karacaören/Günağ 1 Church and the Alakilise Valleys.

Following the field surveys, a second proposal in addition to first one (Fig. 6) was presented by Şahin (Fig. 7). ${ }^{59}$ The connection between Limyra and Arneai has been removed in this proposal. Instead, two roads are introduced, one from Arneai to Tragalassos and the other from Tragalassos to Myra, thus establishing an indirect connection between Arneai and Myra. In this respect this proposal seems to be a better solution. But it leaves Dereağzı as the core-point of the puzzle. It actually does not solve all the problems but leaves some questions unanswered, such as the disconnection between Arneai and Neisa, the doubtful autonomy of Mastaura (Dereağzı?) and Tragalassos (see above p. 91-

\footnotetext{
${ }^{52}$ See the description in Marksteiner 2004, 277-278; see the inscriptions in Wörrle 2012, 446-448 nos. 71-73.

${ }^{53}$ Also mentioned by Şahin 2014, 384.

${ }^{54}$ Wörrle 2012, 423 no. 34.

${ }^{55}$ For the details of the monument and its inscription see Marksteiner - Wörrle 2002.

${ }^{56}$ Marksteiner emphasizes that this part of road represents a new Claudian construction or a large renovation, in Marksteiner - Wörrle 2002, 553.

${ }^{57}$ For the geology, geomorphology and paleogeography of the region around Demre, see Öner 2000; Karaman - Softa - Akan 2010; Keser 2012.

${ }^{58}$ For Belen/Belos see Stark 1958, 179-180; Borchhardt 1975, 90-91; Zimmermann 1992, 113-114; Hellenkemper - Hild 2004, 482-483 (s.v. Belen 1).

${ }^{59}$ Şahin 2014, 280.
} 
92) and does not account for Trebendai.
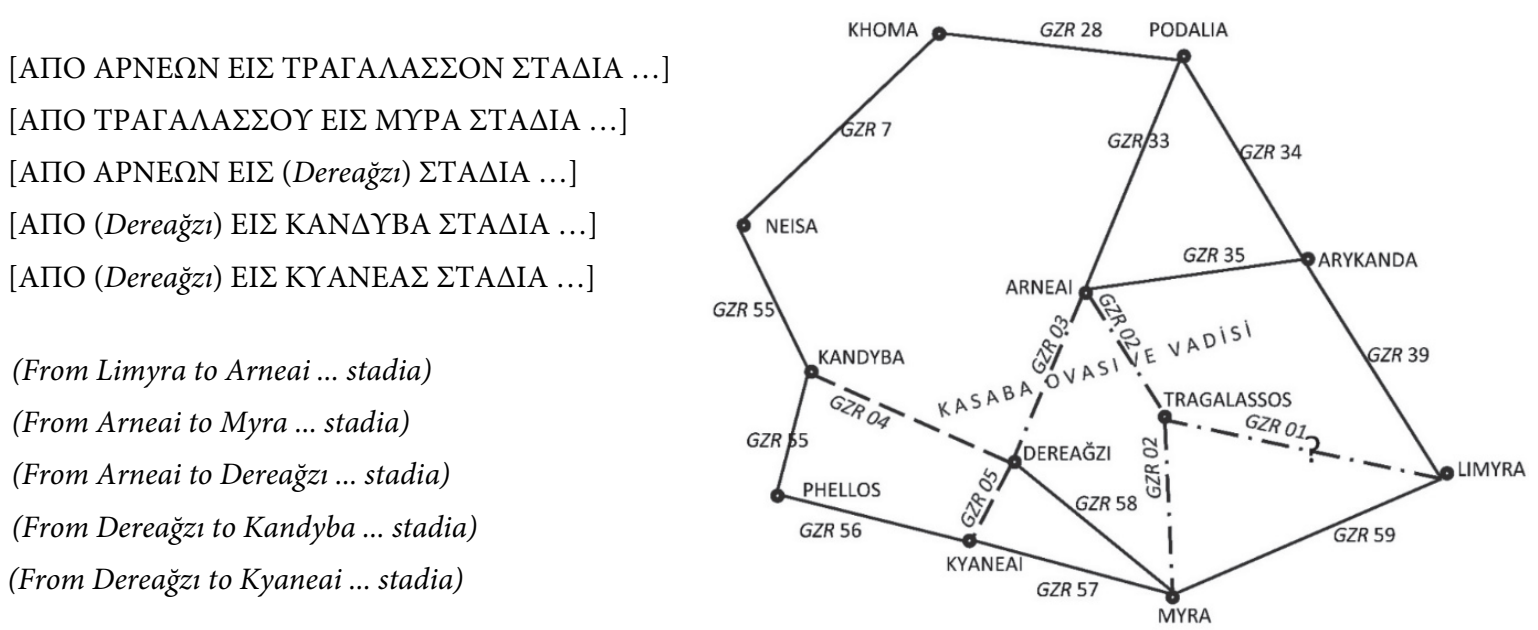

Fig. 7) Second proposal in Şahin 2014, 279-280.

\section{Conclusion}

In order to render the problem simpler, I think that the suggestion to include Dereağzı (Mastaura?) in the SP should be removed from the discussion. Because, as well as being a dependency of Myra, the inclusion of Dereağzı would require the addition of other roads such as Dereağzı-Arneai, Dereağzı-Kyaneai, Dereağzı-Neisa perhaps over Kandyba, would exceed the space allowed for in the blank section of the SP and certainly exclude any reference to the roads Arneai-Limyra, ArneaiTrebendai, Arneai-Neisa, etc. If Mastaura is excluded, then we are dealing with 6 settlements: Arneai, Myra, Limyra, Neisa, Kyaneai and Trebendai, which would fill 5 lines or roads in the blank section of the SP.

Since R 58 might well have run between Myra and Trebendai (see R 58 on the map in Fig. 8), the road leading along the Myros Valley appears to be a connection to Neisa, perhaps through Kandyba (see $\mathrm{R} 04 \mathrm{~b}$ on the map in Fig. 8), and so the remains in the valley were the southern part of the road from Myra to Neisa (see R 04 on the map in Fig. 8), and this link should be placed in the blank section. Based on this, I propose that another road in the blank section was between Trebendai and Arneai (see R 02 on the map in Fig. 8). Since there are traces of roads on the field, one between Arneai and Dereağzı, another between Dereağzı and Kyaneai, the third road in the blank section might have been between Arneai and Kyaneai (see R 03 on the map in Fig. 8), but since such a road would run through the territory of Myra ( $\delta i \grave{a}$ Mú $\rho \omega v)$, there is a lower probability that this road was recorded in the SP (see comments above p. 96-96). So far no proposal has been made for a road between Arneai and Neisa. Şahin thinks that there was no road constructed between these settlements because the area between Arneai and Neisa was not suitable construction and is a landslide area. ${ }^{60}$ This may be true for construction on the lower sections of the slopes, but if the road was at a higher level, i.e. following the modern route through Günçalı, Doğantaş, Ortabağ, Gürsü, Gömüce and Kuruova, then construction may have been possible (see R 05 on the map in Fig. 8).

Finally, a road might have run from Limyra, the destination of the last road on face B, to connect with the geographical flow of the SP, but this is not a necessary conclusion. This road would probably run directly either to Arneai or to Trebendai. Placing a road between Arneai and Limyra, implying

${ }^{60}$ Şahin - Adak 2007, 137; Takmer - Oktan 2013, 64; Şahin 2014, 155. 
that the road led only through the territories of Arneai and Limyra, would mean that these cities were adjacent. We do not know where the boundary between them lay, but it was probably not near Muskar/Belören, if so, the road would have run through the territory of Trebendai or Tragalassos. This may not be an option, if one considers the hypothetical route through Asarönü and Alacadağ to have been too difficult in the very arduous terrain, especially as there were already connections through R39 (Arykanda-Limyra) and R35 (Arneai-Arykanda). Another possibility might be a road from Limyra to Muskar (see R 01b on the map in Fig. 8), from where a road already led to Arneai (see R 02 on the map in Fig. 8). In this case it is unclear what course the road could have followed to Muskar. We cannot know if it was a direct connection, which would not have entered another settlement's territory, or if it was a connection through the territory of Myra. One should also consider that these roads would probably have passed over the Mount Masikytos, in the manner that is explicitly men-

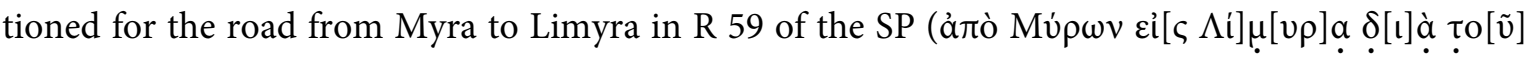

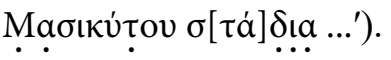

In consequence of these discussions, the proposals for filling the blank section are, as presented on the map below:

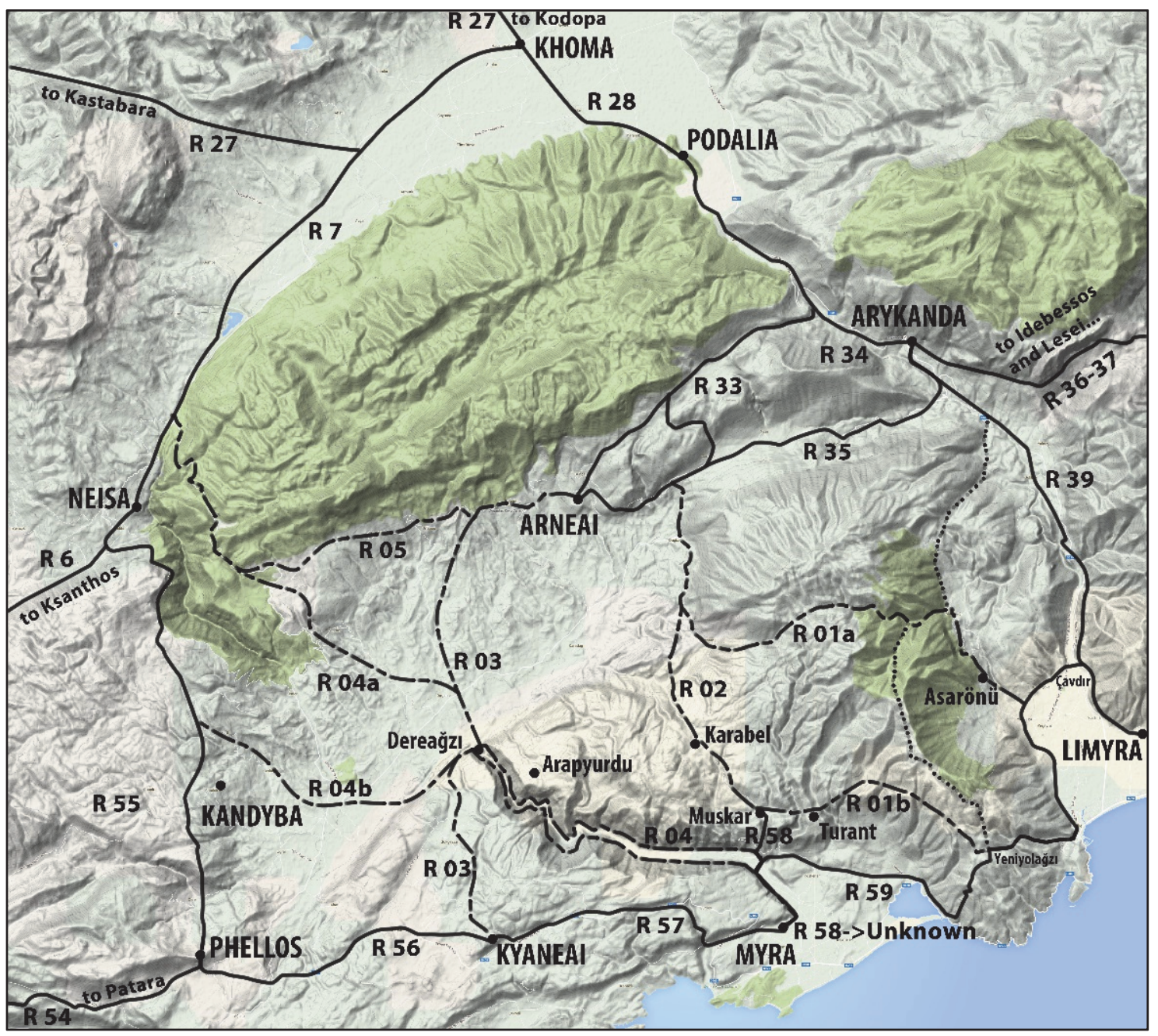

Fig. 8) Possible road connections around Kasaba Plain and Alacadăg 


\section{Bibliography}

Alkan 2011a

Alkan 2011b

Bean 1962

Blum 1997

Borchhardt 1975

Chronz 1985

Çevik 2015

Foss 1991

Foss 1994

Frei 1990

French 1988

French 1993

French 2014

Heberdey - Kalinka 1897

Hellenkemper - Hild 2004

İşler 2010
M. Alkan, A Re-examination of the Sarcophagus Inscription at Turant Asar1, Mediterranean Journal of Humanities I/1, 2011, 33-41. M. Alkan, Parerga to the Stadiasmus Patarensis (8): On the named places in the journeys of sacrifice recorded in the Vita of Saint Nicholas of Holy Sion, Gephyra 8, 2011, 99-124.

G. E. Bean, Report on a Journey in Lycia 1960, Anzeiger Wien 1962, 4-9.

H. Blum, Die Vita Nicolai Sionitae. Griechischer Text. Übersetzt und kommentiert, Bonn 1997.

J. Borchhardt (ed.), Myra. Eine lykische Metropole in antiker und byzantinischer Zeit, Berlin 1975.

M. Chronz, Die Vita des heiligen Nikolaos Sionites. Übersetzung - Anmerkungen - Kommentar (Unpublished phil. thesis, Univ. Würzburg), Würzburg 1985.

N. Çevik, Lykia Kitabı, İstanbul 2015.

C. Foss, Cities and Villages of Lycia in the Life of St. Nicholas of Holy Sion, Greek Orthodox Theological Review 36, 1991, 303-339.

C. Foss, The Lycian Coast in the Byzantine Age, Dumbarton Oaks Papers 48, 1994, 1-52.

P. Frei, Die Götterkulte Lykiens in der Kaiserzeit, ANRW II.18.3, 1990, 1729-1864.

D. French, Roman Roads and Milestones of Asia Minor (Vol. II.1), Oxford 1988.

D. French, The Road, Paths, and Water Channel, in: J. Morganstern (ed.), The Fort at Dereağzı and Other Material Remains in Its Vicinity: From Antiquity to The Middle Ages, Tübingen 1993, 87-90.

D. French, Roman Roads \& Milestones of Asia Minor (Vol. 3. Milestones. Fasc. 3.6 Lycia et Pamphylia), 2014: British Institute at Ankara, online edition.

R. Heberdey - E. Kalinka, Bericht über zwei Reisen im südwestlichen Kleinasien, Vienna 1897.

H. Hellenkemper - F. Hild, Lykien und Pamphylien I-III (Tabula Imperii Byzantini 8; Österreichische Akademie der Wissenschaften. Philosophisch-historische Klasse. Denkschriften 320), Vienna 2004.

B. İşler, Myra ve Çevresinde Bizans Dönemi, in: N. Çevik (ed.), Arkeolojisinden Doğasına Myra/Demre ve Çevresi, Antalya 2010, 233-255. 
Jameson 1980

Karaman - Softa - Akan 2010

Keser 2012

LNS

Magie 1950

Marksteiner 2004

Marksteiner - Wörrle 2002

Marksteiner et al. 2007

Morganstern 1968

Onur 2015

Öner 1996

Öner 2000

Öztürk 2011

Petersen - von Luschan 1889

Robert 1955

Ruge 1937

Schuler 2014
S. Jameson, The Lycian League: Some Problems in its Administration, in: ANRW II 7.2, Berlin/New York 1980, 832-855.

M. E. Karaman - M. Softa - G. Akan, Demre (Antalya) ve Çevresinin Jeolojik Yapısı, in: N. Çevik (ed.), Arkeolojisinden Doğasına Myra/ Demre ve Çevresi, Antalya 2010, 329-337.

N. Keser, Demre Çayının Paleocoğrafi Dönem Vadi Değişiklikleri ve Beymelek Lagünü'nün Jeomorfolojik Evrimi, Doğu Coğrafya Dergisi 17/28, 2012, 175-192.

I. Sevcenko - N. P. Sevcenko (trans.), The Life of Saint Nicholas of Sion, Brookline, Massachusetts 1984.

D. Magie, Roman Rule in Asia Minor I-II, Princeton 1950.

T. Marksteiner, Der Bonda-Survey: Archäologische Feldforschungen auf dem Territorium der ostlykischen Polis Limyra, in: F. Kolb (ed.), Chora und Polis (Schriften des Historischen Kollegs. Kolloquien 54), Munich 2004, 271-290.

T. Marksteiner - M. Wörrle, Ein Altar für Kaiser Claudius auf dem Bonda, Chiron 32, 2002, 545-564.

T. Marksteiner - B. Stark - M. Wörrle - B. Yener-Marksteiner, Der Yalak Başı auf dem Bonda Tepesi in Ostlykien. Eine dörfliche Siedlung und ein ländlicher Kultplatz im Umland von Limyra, Chiron 37, 2007, 243-293.

J. Morganstern, The Church at Dereğzı: A Preliminary Report, Dumbarton Oaks Papers 22, 1968, 217-225.

F. Onur, Stadiasmus Patarensis'te Yollar, Yerleşimler ve Teritoryumlar, in: N. Eda Akyürek Şahin - M. E. Yıldız - H. Uzunoğlu (edd.), Eskiçağ Yazıları 8 (AKRON 10), İstanbul 2015 (in print).

E. Öner, Finike Ovasının Alüvyal Jeomorfolojisi ve Antik Limyra Kenti, Ege Coğrafya Dergisi 9, 1996, 131-158.

E. Öner, Demre Çayı Deltasının Jeomorfolojik Gelişimi ve Myra Antik Kenti Limanı ve St. Nicholaus Kilisesi, Arkeometri Sonuçları Toplantisı 16, 2000, 1-18.

H. S. Öztürk, Muskar (Myra/Lykia): İki Yazıta Addendum et corrigendum, Colloquium Anatolicum 10, 2011, 209-218.

E. Petersen - F. von Luschan, Reisen in Lykien, Milyas und Kibyratis (Reisen im südwestlichen Kleinasien II), Vienna 1889.

L. Robert, Villes et Monnaies de Lycie, Hellenica X, 1955, 188-222.

W. Ruge, Trebendai, in: RE VI A/2 1937, 2267-2268.

C. Schuler, Verträge zwischen kleinen Poleis in hellenistischer Zeit: Die Symmachie zwischen Arykanda und Tragalassos, in: V. Cojocaru - C. Schuler (edd.), Die Außenbeziehungen pontischer und kleinasiatischer Städte in hellenistischer und römischer Zeit, Akten einer deutsch-rumänischen Tagung in Constanţa, 20.-24. 
Stark 1958

Şahin 2011

Şahin 2014

Şahin - Adak 2004

Şahin - Adak 2007

Takmer 2004

Takmer - Alkan 2013

Takmer - Oktan 2013

Troxell 1982

Uzunoğlu - Taşdelen 2013

Wörrle 1999a

Wörrle 1999b

Wörrle 2012

Zimmermann 1992

Zimmermann 2002
September 2010, Stuttgart 2014, 275-301.

F. Stark, Alexander's Path: from Caria to Cilicia, London 1958.

S. Şahin, Parerga to Stadiasmus Patarensis (5): STR 59 and Daseia of Bonda, Gephyra 8, 2011, 55-63.

S. Şahin, Stadiasmus Patarensis. Itinera Romana Provinciae Lyciae, İstanbul 2014

S. Şahin - M. Adak, Stadiasmus Patarensis. Ein zweiter Vorbericht über das claudische Straßenbauprogramm in Lykien, in: R. FreiStolba (ed.), Siedlung und Verkehr im römischen Reich. Römerstraßen zwischen Herrschaftssicherung und Landschaftsprägung. Akten des Internationalen Kolloquiums zu Ehren von Heinz E. Herzig, Bern 27-30.06.2001, Bern 2004, 227-277.

S. Şahin - M. Adak, Stadiasmus Patarensis. Itinera Romana Provinciae Lyciae, İstanbul 2007.

B. Takmer, Two Milestones on the Road from Myra to Limyra, Gephyra 1, 2004, 107-117.

B. Takmer - M. Alkan, Parerga to the Stadiasmus Patarensis (13): The road system in the mountainous area of Alacadağ in central Lycia and the roads indicated in the Vita of Nicholas of Sion, Gephyra 10, 2013, 106-120.

B. Takmer - M. Oktan, Parerga zum Stadiasmus Patarensis (11): Die lykische Stadt Neisa, Gephyra 10, 2013, 50-96.

H. A. Troxell, The Coinage of the Lycian League (Numismatic Notes and Monographs 162), New York, 1982.

H. Uzunoğlu - E. Taşdelen, Parerga to the Stadiasmus Patarensis (14): Die Strecken 35 (Arykanda - Arneai) und 37 (Arykanda Lesei-), Gephyra 10, 2013, 121-131.

M. Wörrle, Epigraphische Forschungen zur Geschichte Lykiens VII: Asarönü, ein Peripolion von Limyra, Chiron 29, 1999, 353-370.

M. Wörrle, Artemis und Eleuthera in Limyra, in: P. Scherrer - H. Taeuber - H. Thür (edd.), Steine und Wege. Festschrift für Dieter Knibbe zum 65. Geburstag, Vienna 1999, 269-274.

M. Wörrle, Die griechischen Sepulkralinschriften von Limyra, in: J. Borchhardt - A. Pekridou-Gorecki (eds.), Studien zu Kunst und Epigraphik in den Nekropolen der Antike, Vienna 2012, 411-457. M. Zimmermann, Untersuchungen zur historischen Landeskunde Zentrallykiens, Bonn 1992.

M. Zimmermann, Trebendai, in: DNP 12/1, 2002, 776. 


\section{Stadiasmus Patarensis için Parerga (15): Kasaba Ovası Çevresinin Yol Ağı Özet}

Bu makalede Kasaba Ovası'nda Stadiasmus Patarensis (SP) kapsamında eksik olan kısımlar ve Alacadağ üzerindeki bazı yol bağlantıları ele alınmaktadır. Dereağzı etrafındaki yol ağı sorunlarına çözüm sunabilecek ve yazıttaki Myra'dan verilen Y 58'in hedefinin okunamaması, Arneai ve Dereağzı çevresindeki bazı yolların eksikliği ve yazıtın $C$ yüzünün üst kısmındaki boş alan çeşitli sorunları beraberinde getirmektedir. Myra çıkışlı iki yoldan bir tanesi Limyra'ya giderken, diğer yolun hedefi (Y 58), yazıtlı bloğun aşınmasından dolayı kesin bir şekilde tamamlanamamaktadır. Bu hedefe yönelik öneriler arasında Dereağzı (Mastaura?) ve Arneai bulunmaktadır. Yazar SP yerleşimlerinin otonom olmalarından ve yolların coğrafik olarak araziye yerleştirilmesi açısından bu önerileri olası görmemektedir. Hedef olarak ise, Trebendai kentini önermektedir. Kasaba Ovası'na denk gelen ve yazıtta eksik olan yolların anıt üzerindeki boş kısma yerleştirilmesi gerektiğinden ve devamı C yüzünde olan B yüzünün son yol bilgisinin Arykanda'dan Limyra'ya (Y 39) verilmiş olmasından hareketle, yazar bu boş kısımdaki ilk yolun (daha önce Sencer Şahin tarafından da önerilen) Limyra'dan Arneai'a ya da kendi önerisi olarak Trebendai'a verilmiş olabileceğini belirtmektedir. Yazar ayrıca Dereağzı’nın (Mastaura?) söz konusu boş kısma yönelik tartışmalardan çıkarılması gerektiğini vurgulayarak boş kesimdeki yolları Arneai, Myra, Limyra, Neisa, Kyaneai ve Trebendai arasında kurgulamaktadır.

Anahtar Sözcükler: Lykia; Roma yolları; Trebendai; Arneai; Myra; Tragalassos; Mastaura; Dereağzı.

\section{Parerga to the Stadiasmus Patarensis (15): The Road Network around Kasaba Plain} Abstract

This article examines some missing parts concerning the Kasaba Plain and some road connections on Alacadağ, in respect to the Stadiasmus Patarensis (SP). The unknown destination of R 58 (from Myra) that is connected with the road network problems around Dereağzl, the absence of some important roads around Arneai and Dereağzı, and the blank section on top of Face C of the SP present some puzzling issues. One of two roads from Myra is Limyra (R 59), while the destination of other can unfortunately be restored insecurely due to erosion in the relevant part on the block. The propositions as to this destination are Dereağzı (Mastaura?) and Arneai. The author finds these propositions unlikely based upon the autonomy of the settlements and their geographical adaptability both in the field and on the SP, and proposes Trebendai, as an autonomous settlement near to Myra. Since the missing roads around the Kasaba Plain should fit in the blank section, the author discusses if the first road in the blank section could have been to Arneai (as was proposed by Şahin) or to Trebendai from Limyra, which is the last station in the road given from Arykanda (R 39) in the list on Face B that continues with the blank section on Face C. The author removes Dereağzı (Mastaura?) from the former propositions and establishes the roads in the blank section between Arneai, Myra, Limyra, Neisa, Kyaneai and Trebendai.

Keywords: Lycia; Roman roads; Trebendai; Arneai; Myra; Tragalassos; Mastaura; Dereağzı. 


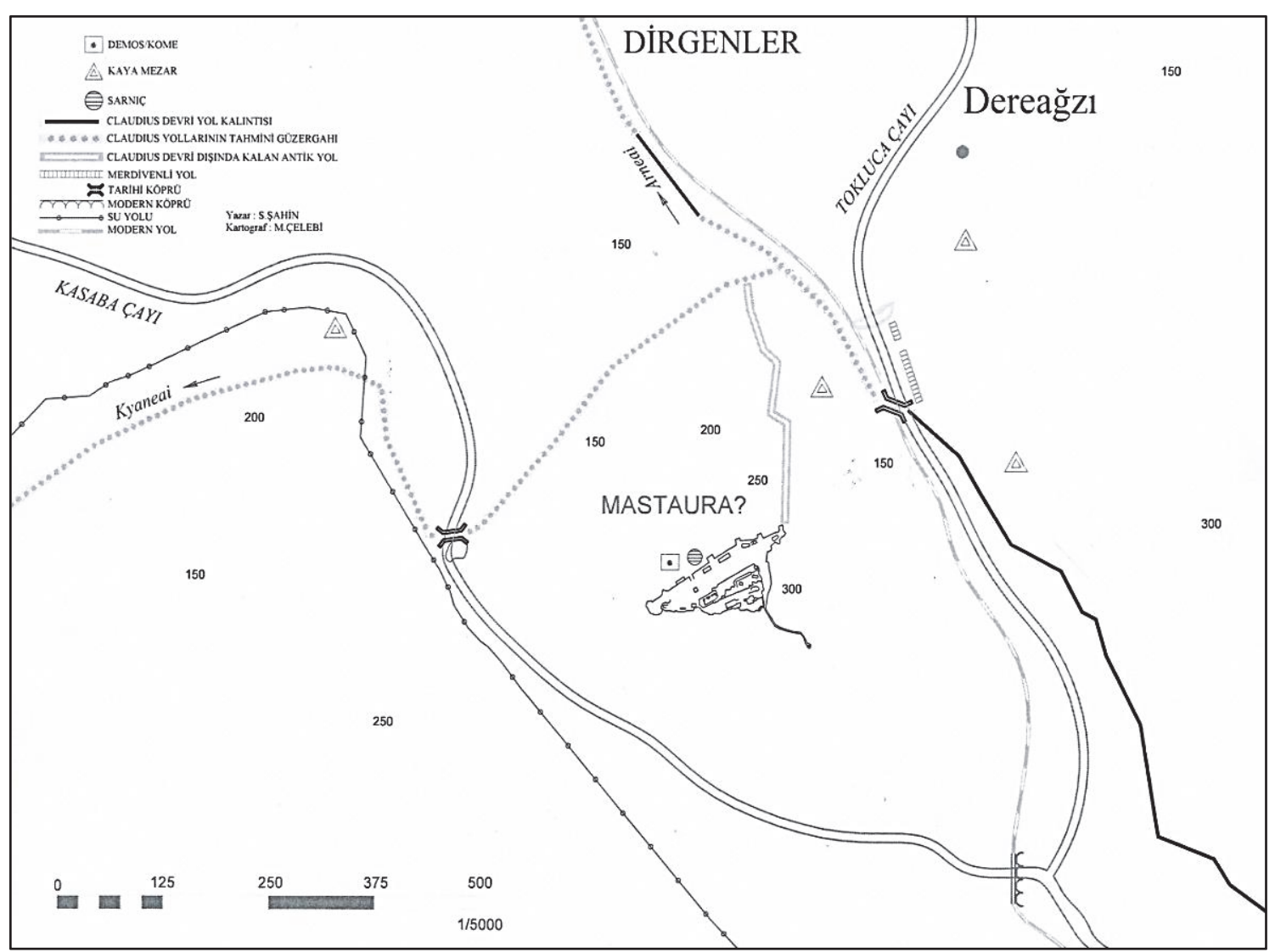

Fig. 9) Topographical plan of the Dereağzı region (S. Şahin - M. Çelebi).

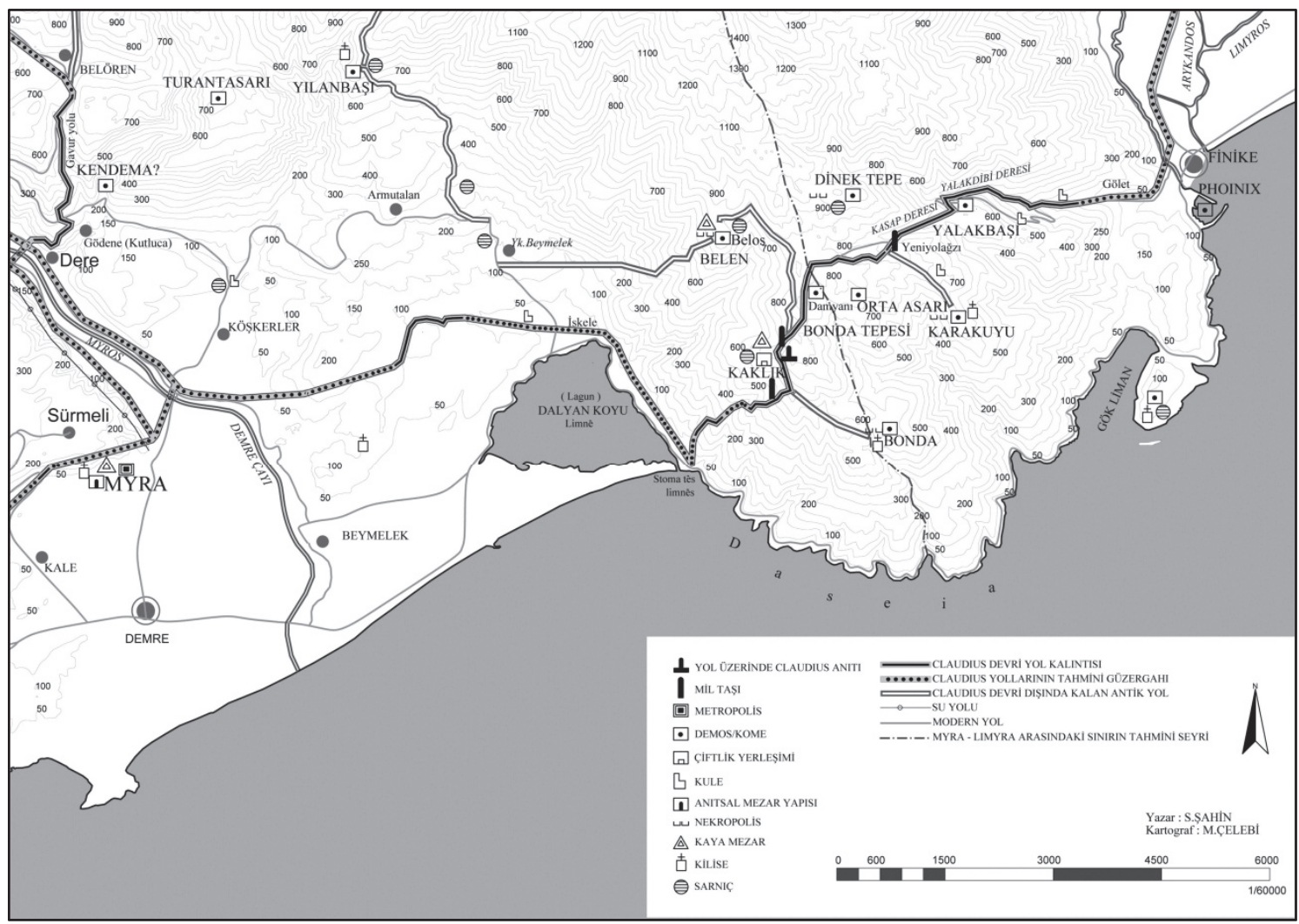

Fig. 10) The region between Myra and Limyra (Şahin 2011, 56 Karte 1). 


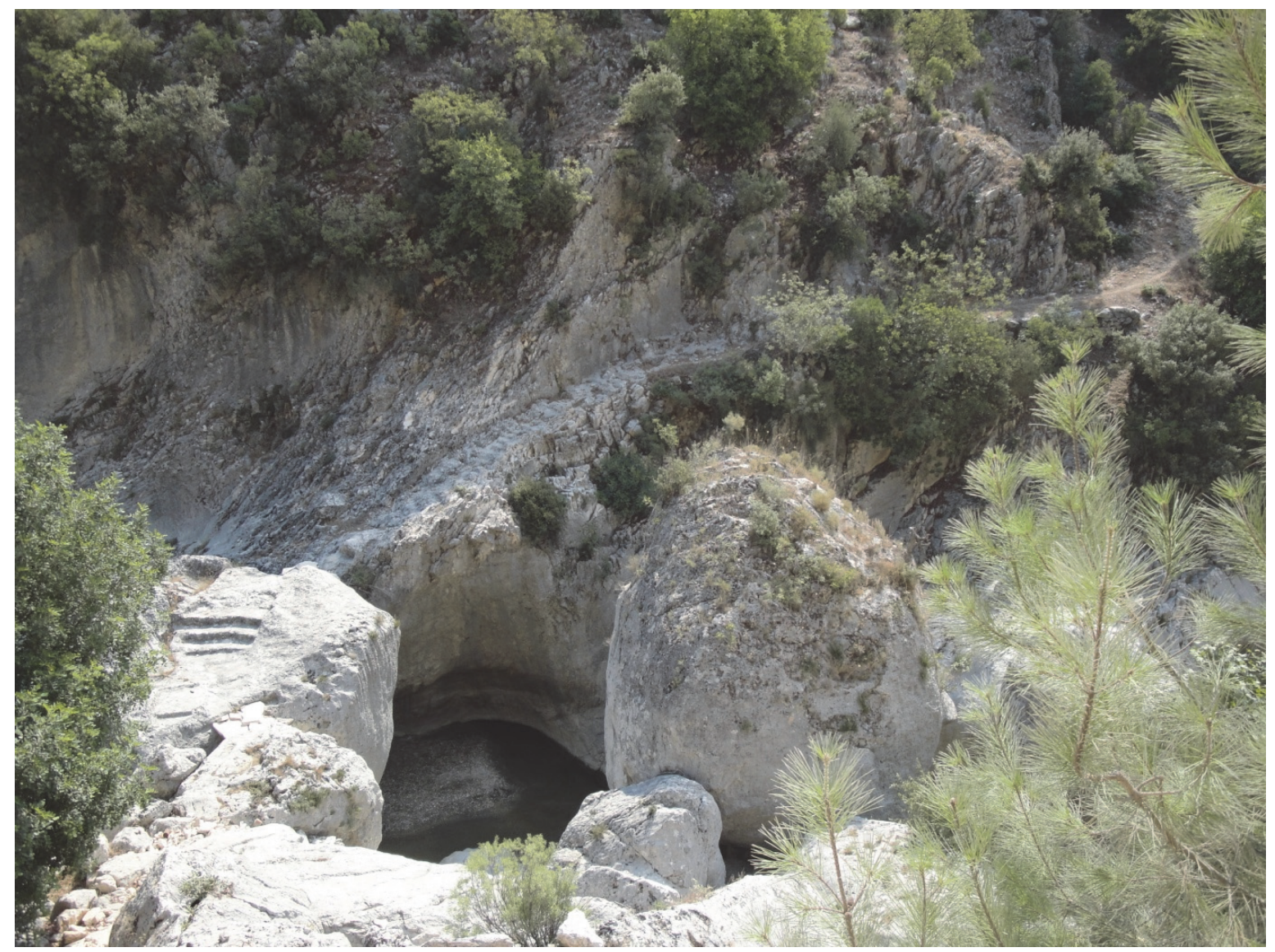

Fig. 11) The natural bridge over the Tokluca (Karadă̆) Çayı on the eastern side of Dereağzı at the entrance of the straits and the steps leading towards the south.

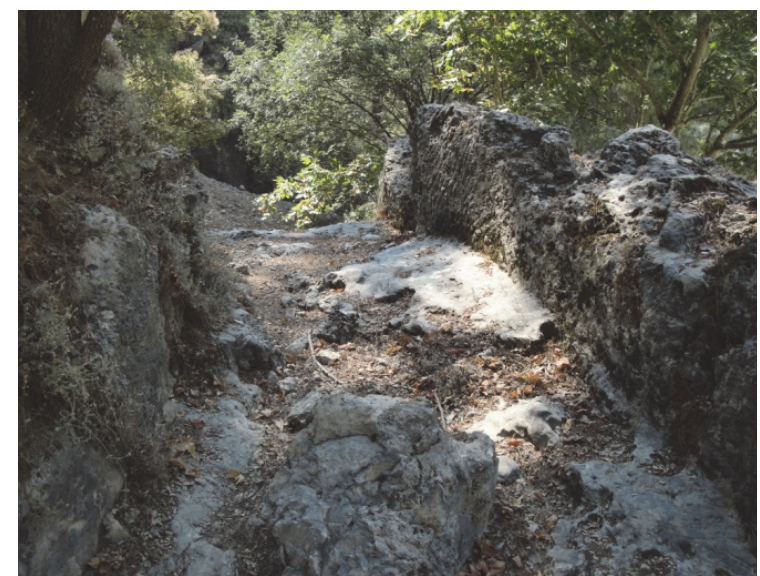

Fig. 12) A rock-cut section of the road on the eastern bank of the Myros River.

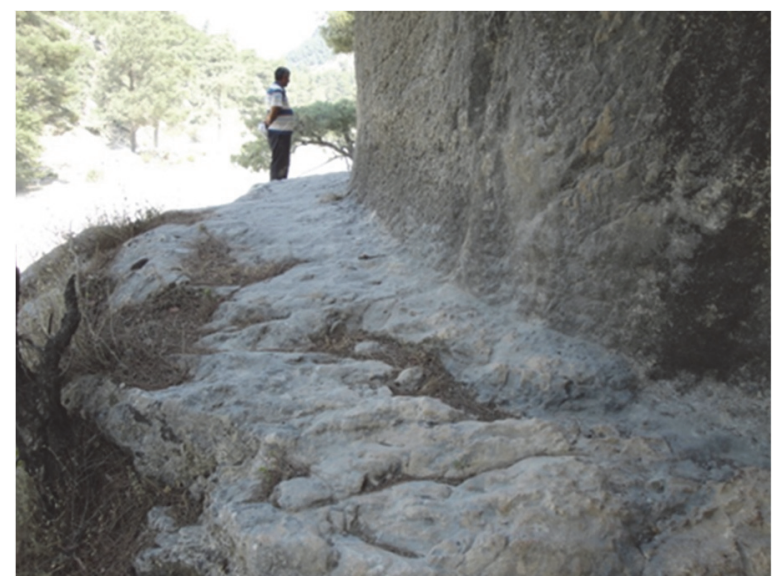

Fig. 13) A rock-cut section of the road on the eastern bank of the Myros River. 


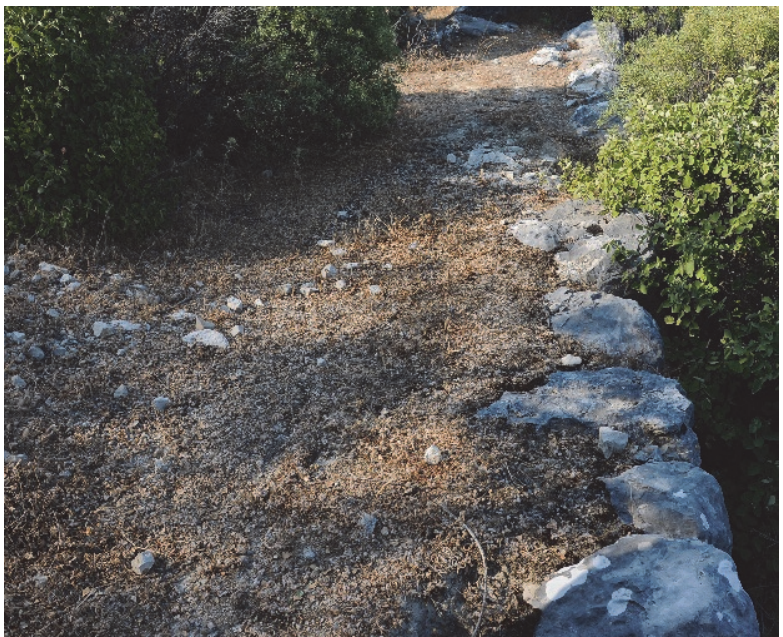

Fig. 14) The road to the south of Kandyba

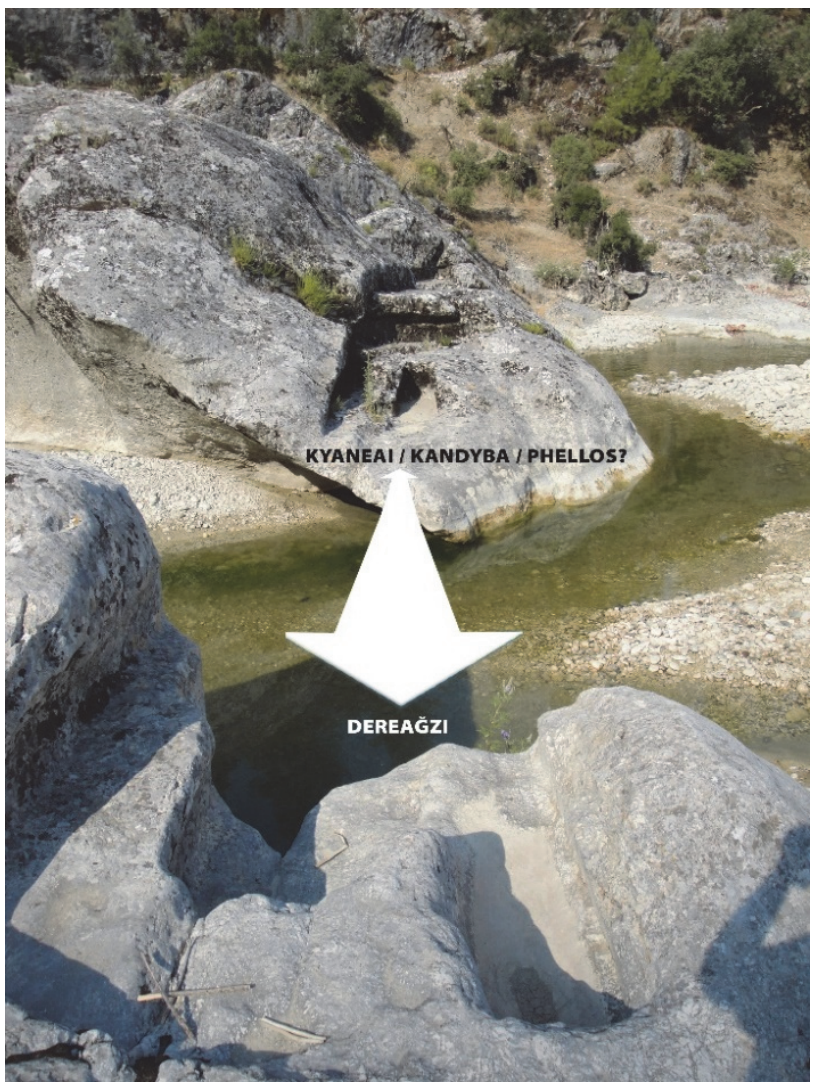

Fig. 16) The remains of the footings of the wooden bridge over the Kasaba River at the western foot of Dereağzı Hill

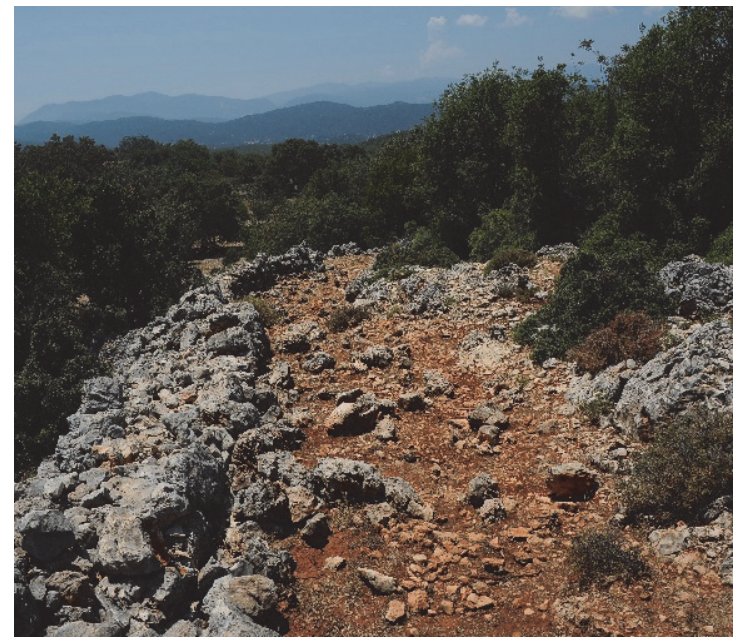

Fig. 15) The road near Köte

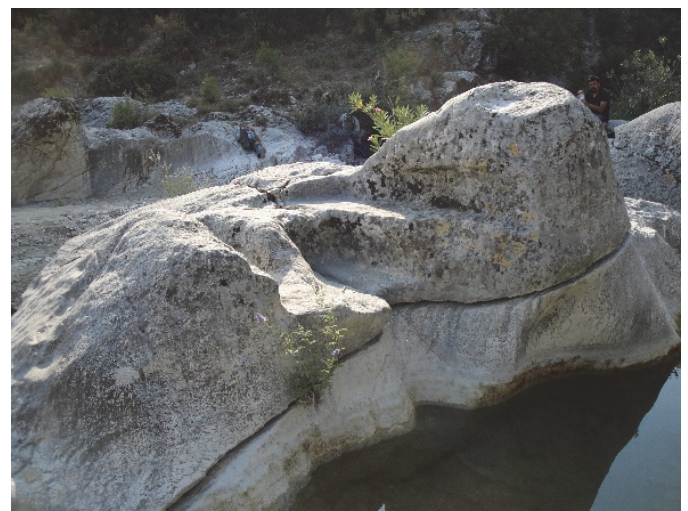

Fig. 17) Eastern footing of the wooden bridge

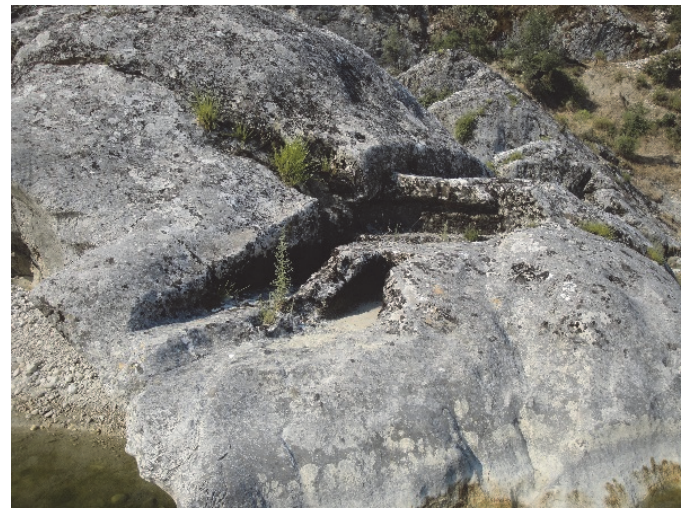

Fig. 18) Western footing of the wooden bridge 


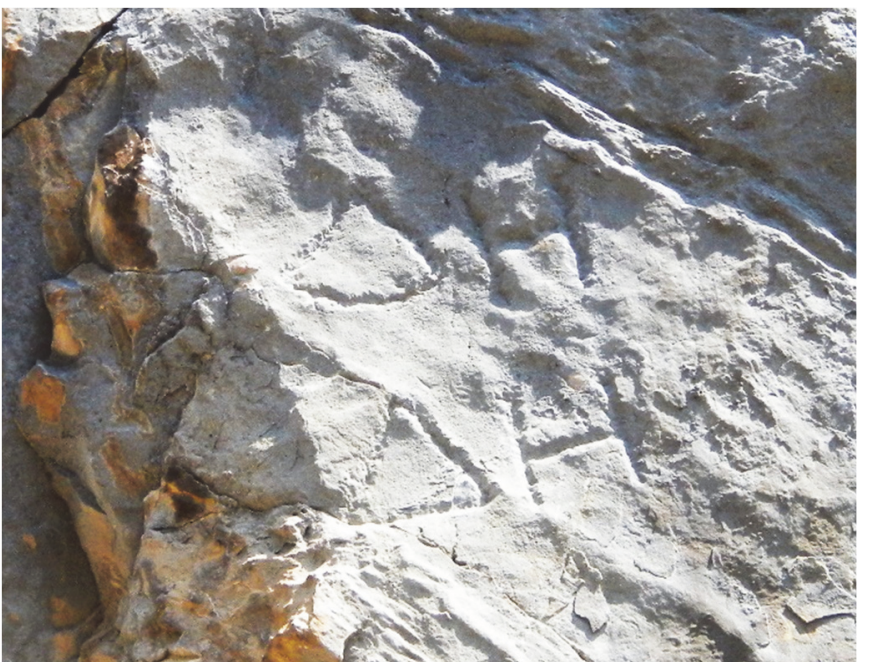

Fig. 19) Boundary (?) inscriptions on the bedrock in the Valley of the Sirlan Deresi (Photo: Pinar Bursa Sturdevant)

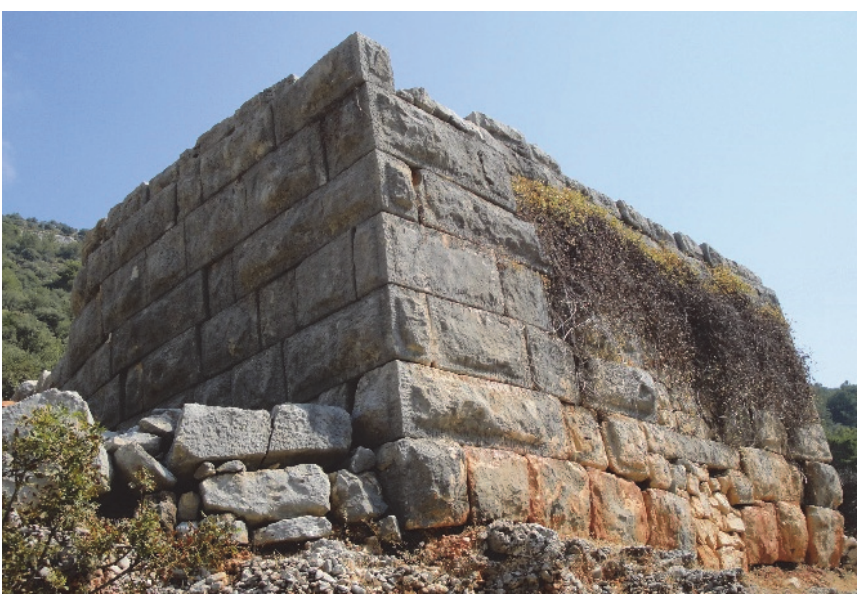

Fig. 20) Hellenistic tower to the north of Finike on the way to Myra

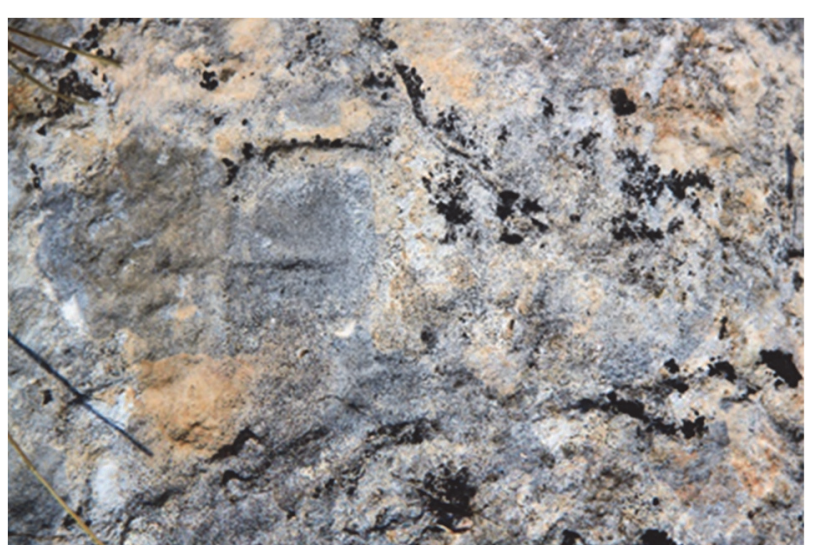

Fig. 22) Number(s) on the milestone near Yeniyolağzı

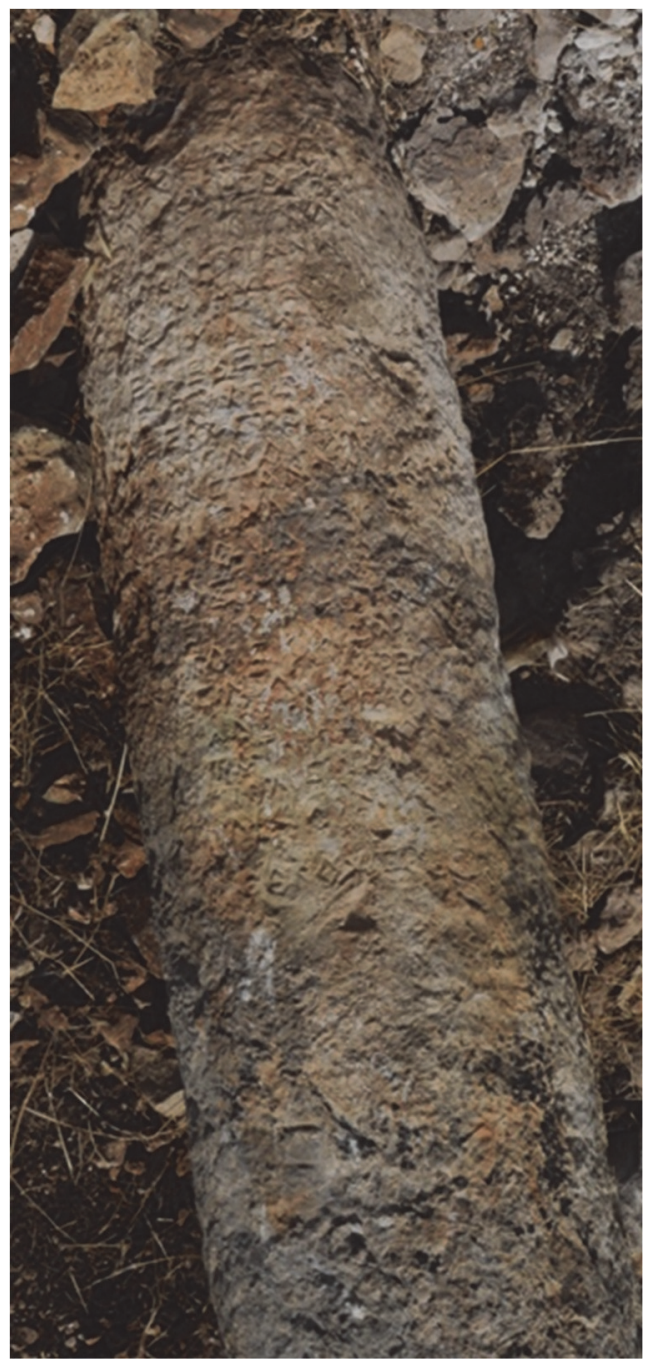

Fig. 21) The milestone near Yeniyolağzı / Damyanı

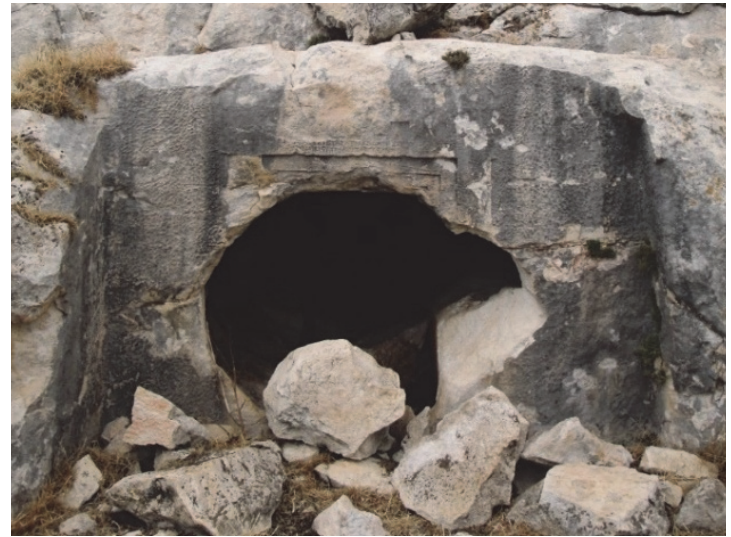

Fig. 23) The tomb of Kendas 


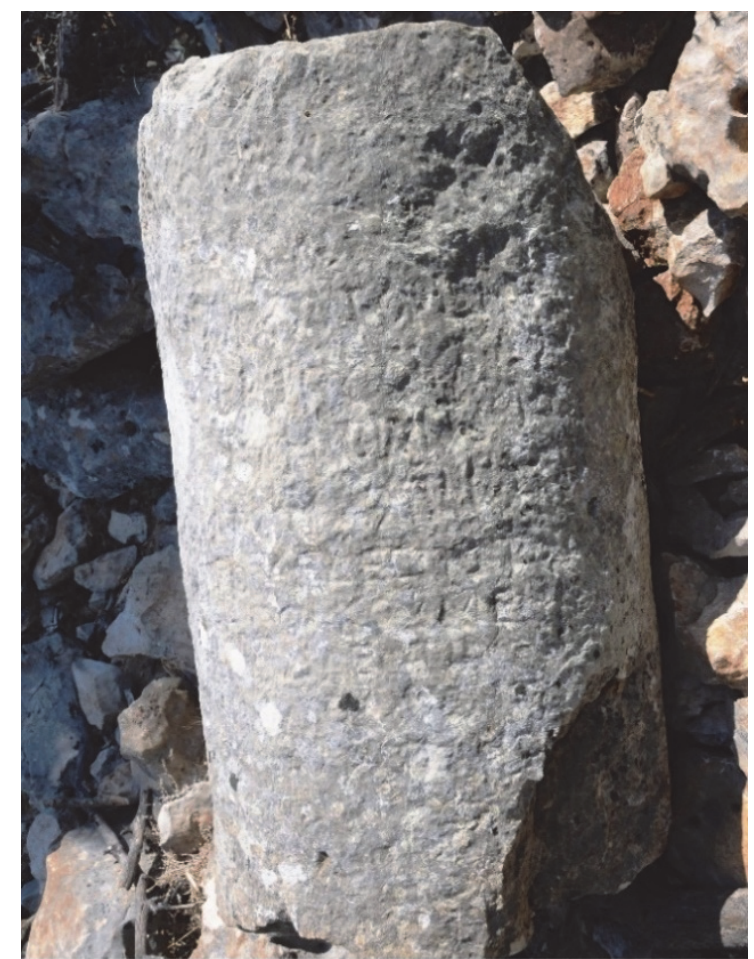

Fig. 24a) The milestone near Kaklik

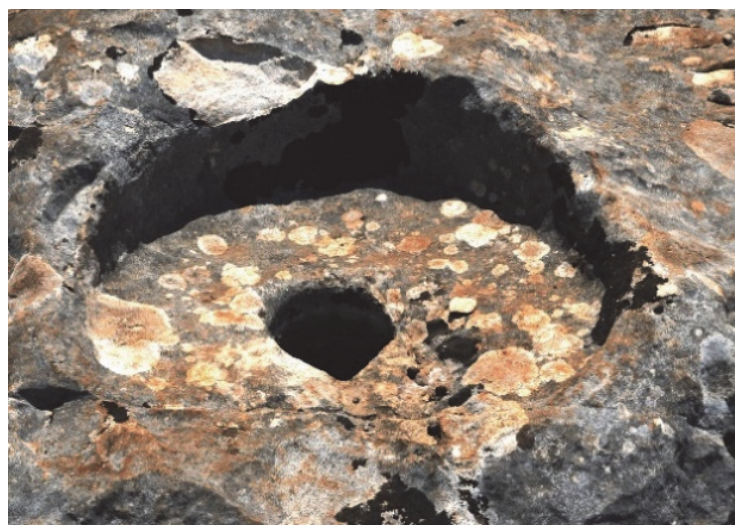

Fig. 24b) Probable rock-cut seating of the milestone near Kaklik

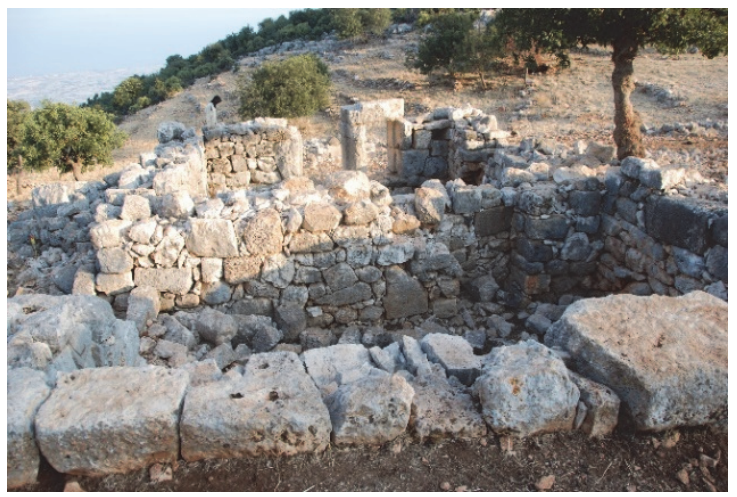

Fig. 28) The ruins nearby the top of Asarbelen Tepesi (Muskar)

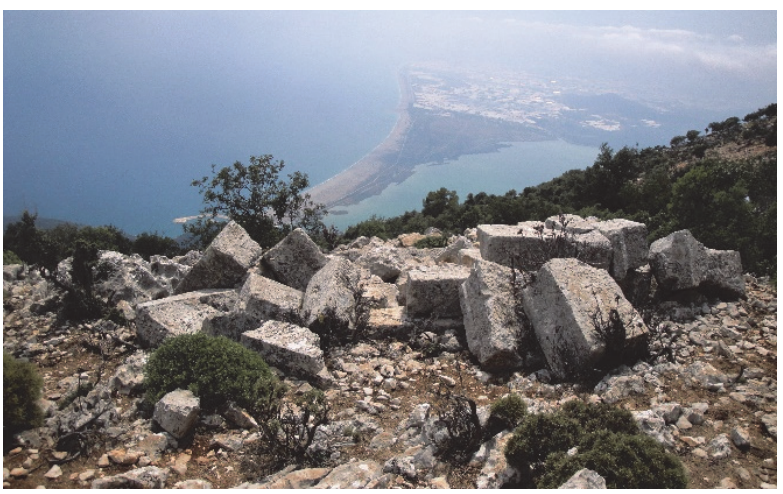

Fig. 25) The Claudian Monument on Bonda Tepesi

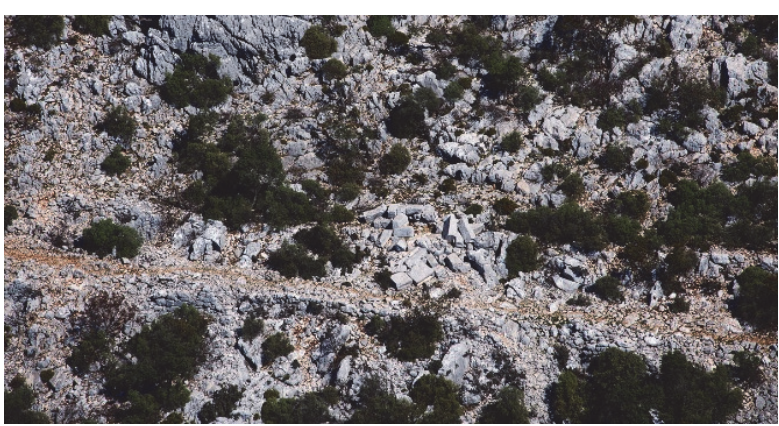

Fig. 26) The Claudian Monument and the ancient road

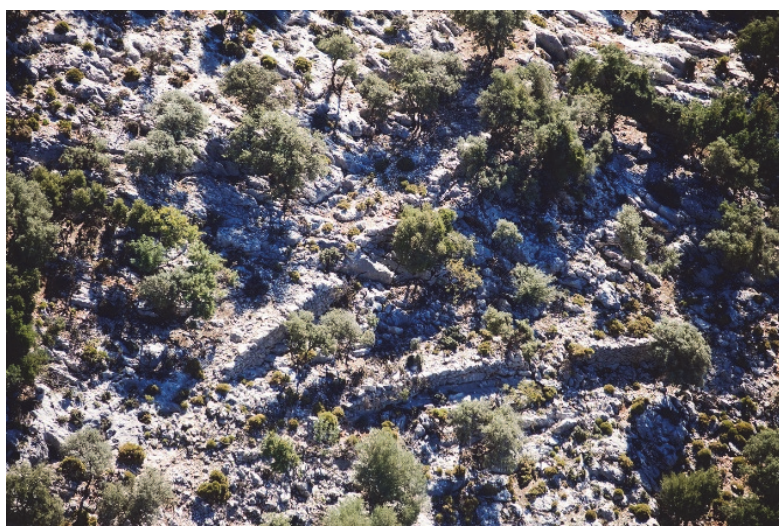

Fig. 27) The zigzags of the ancient road on the western slope of Bonda Tepesi

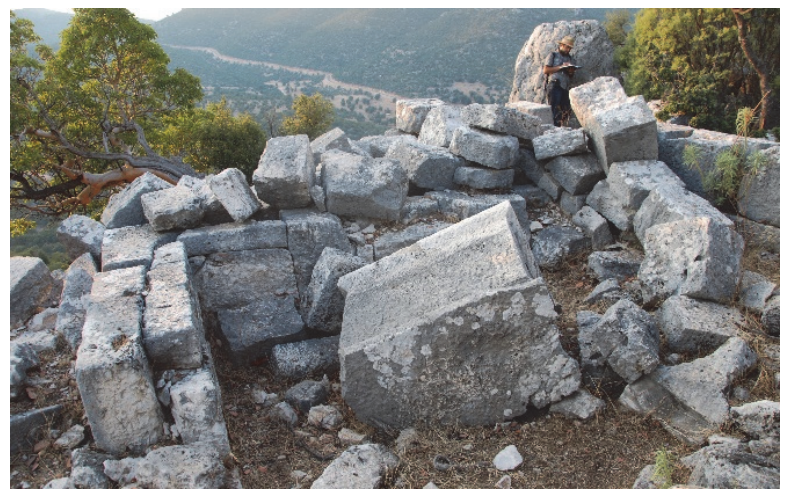

Fig. 29) The ruins at the top of Asarbelen Tepesi (Muskar) 